\title{
Synapse-Associated Protein 97 Regulates the Membrane Properties of Fast-Spiking Parvalbumin Interneurons in the Visual Cortex
}

\author{
Gulcan Akgul ${ }^{1}$ and Lonnie P. Wollmuth ${ }^{2}$ \\ ${ }^{1}$ Graduate Program in Molecular and Cellular Biology and ${ }^{2}$ Department of Neurobiology and Behavior, Center for Nervous System Disorders, Stony Brook \\ University, Stony Brook, New York 11794-5230
}

\begin{abstract}
Fast-spiking parvalbumin (PV)-positive interneurons in layers $2 / 3$ of the visual cortex regulate gain control and tuning of visual processing. Synapse-associated protein 97 (SAP97) belongs to a family of proteins that have been implicated in regulating glutamatergic synaptic transmission at pyramidal-to-pyramidal connections in the nervous system. For PV interneurons in mouse visual cortex, the expression of SAP97 is developmentally regulated, being expressed in almost all juvenile but only a fraction, 40\%, of adult PV interneurons. Using whole-cell patch-clamping, single-cell RT-PCR to assay endogenous expression of SAP97 and exogenous expression of SAP97, we investigated the functional significance of SAP97 in PV interneurons in layers 2/3 of the visual cortex. PV interneurons expressing SAP97, either endogenously or via exogenous expression, showed distinct membrane properties from those not expressing SAP97. This included an overall decrease in membrane excitability, as indexed by a decrease in membrane resistance and an increase in the stimulus threshold for the first action potential firing. Additionally, SAP97-expressing PV interneurons fired action potentials more frequently and, at moderate stimulus intensities, showed irregular or stuttering firing patterns. Furthermore, SAP97-expressing PV interneurons showed increased glutamatergic input and more extensive dendritic branching when compared with non-expressing PV interneurons. These differences in membrane and synaptic properties would significantly alter how PV interneurons expressing SAP97 compared with those not expressing SAP97 would function in local networks. Thus, our results indicate that the scaffolding protein SAP97 is a critical molecular factor regulating the input- output relationships of cortical PV interneurons.
\end{abstract}

\section{Introduction}

Parvalbumin $(\mathrm{PV})$-positive $\left(\mathrm{PV}^{+}\right)$interneurons are the most prominent GABAergic interneuron in the cortex (Gonchar et al., 2007), contributing to excitation-inhibition balance and oscillatory activity (Cardin et al., 2009). Disruption of PV interneuron function results in behavioral abnormalities and cognitive deficits and has pathological consequences, such as epilepsy, schizophrenia, and autism (Curley and Lewis, 2012; Marín, 2012).

PV interneurons target the perisomatic region and have strong control over the generation of action potentials (APs) in pyramidal neurons (Freund and Katona, 2007; Merchán-Pérez et al., 2009). The balance of the excitatory and inhibitory input PV

Received Jan. 4, 2013; revised June 17, 2013; accepted June 27, 2013.

Author contributions: G.A. and L.P.W. designed research; G.A. performed research; G.A. and L.P.W. analyzed data; G.A. and L.P.W. wrote the paper.

This work was supported by National Institutes of Health/National Eye Institute R01 Grant EY01697905 (L.P.W.). We thank Drs. Paul Adams, Mark Bowen, and Arianna Maffei for helpful discussions and/or comments on this manuscript, Dr. Josh Huang and his laboratory for assistance with mice, Drs. David Talmage, Arianna Maffei, Shaoyu Ge, Yan Gu, Diane Henry-Vanisko, and Janet Allopenna for technical advice and/or assistance, and Dr. Robert Malenka for supplying $\alpha$-SAP97.

G. Akgul's present address: Laboratory of Cellular and Synaptic Neurophysiology, Eunice Kennedy Shriver National Institute of Child Health and Human Development, National Institute of Health, Bethesda, MD 20892.

Correspondence should be addressed to Dr. Lonnie P. Wollmuth, Department of Neurobiology and Behavior, Center for Nervous System Disorders, Stony Brook University, Stony Brook, NY 11794-5230. E-mail: lonnie.wollmuth@stonybrook.edu.

DOI:10.1523/JNEUROSCI.0040-13.2013

Copyright $\odot 2013$ the authors $\quad 0270-6474 / 13 / 3312739-12 \$ 15.00 / 0$ interneurons receive as well as their intrinsic membrane properties regulate their inhibitory output. PV interneurons are characterized by fast-spiking firing patterns (Cauli et al., 1997; Miyoshi et al., 2007; Okaty et al., 2009) and, compared with regularspiking pyramidal neurons, express a distinct array of voltagesensitive ion channels (Rudy and McBain, 2001; Jonas et al., 2004; Goldberg et al., 2008). The excitatory glutamatergic inputs that PV interneurons receive compared with that for pyramidal neurons is also distinct, expressing high levels of $\mathrm{Ca}^{2+}$-permeable AMPA receptors (AMPARs) and limited levels of NMDA receptors (NMDARs) (Geiger et al., 1995; Angulo et al., 1997; Goldberg et al., 2003).

Synapse-associated protein 97 (SAP97) is a member of the membrane-associated guanylate kinase (MAGuK) family of scaffolding proteins (Sheng and Hoogenraad, 2007). SAP97 is associated with components of the postsynaptic density at glutamatergic synapses onto pyramidal neurons; however, its exact function in synaptic transmission remains controversial. SAP97 interacts with the AMPAR GluA1 subunit (Leonard et al., 1998), which is $\mathrm{Ca}^{2+}$ permeable, as well as specific NMDAR subunits (Cousins et al., 2008), and it might contribute to receptor clustering and trafficking (Elias and Nicoll, 2007; Stephenson et al., 2008). SAP97 also mediates transynaptic communication, possibly through cell adhesion molecules (Regalado et al., 2006). In cardiac myocytes, SAP97 has been implicated in regulating membrane excitability via interactions with $\mathrm{K}^{+}$and $\mathrm{Na}^{+}$channels, 
including altering their clustering at the membrane (Abi-Char et al., 2008; Milstein et al., 2012) and affecting their biophysical properties (Vikstrom et al., 2009). Although SAP97 and $\mathrm{K}^{+}$channel interactions occur in neurons (Tiffany et al., 2000; Leonoudakis et al., 2004), a role of SAP97 in regulating neuronal membrane properties is unknown.

SAP97 expression in cortical PV interneurons is developmentally regulated, being expressed in a higher fraction of juvenile than in adult interneurons (Akgul and Wollmuth, 2010). Still, a significant fraction of PV interneurons in adult visual cortex, $\sim 40 \%$, express SAP97. To address the functional consequences of SAP97 expression in PV interneurons, we used whole-cell patch clamp to monitor membrane and synaptic properties of PV interneurons and assayed SAP97 expression using single-cell RT-PCR. We find that $\mathrm{SAP}^{+}{ }^{+} \mathrm{PV}$ interneurons exhibit a distinct membrane phenotype of low excitability and higher-frequency action potential (AP) firing, demonstrating for the first time that SAP97 regulates membrane excitability in neurons. SAP97 expression also affects glutamatergic input. Exogenous expression of SAP97 in PV interneurons drives their mem-

brane and synaptic properties toward the endogenous SAP97 ${ }^{+}$phenotype, indicating that SAP97 has a causal role.

\section{Materials and Methods \\ Animals}

Two transgenic mouse lines were used to identify PV interneurons in the visual cortex: PV-Cre and lox-STOP-lox-tdTomato (LSL-tdTomato). The PV-Cre line has expression of Cre recombinase driven by a PV promoter (an IRES-Cre-pA cassette inserted at the $3^{\prime}$ end of the PV gene) (Hippenmeyer et al., 2005; Kuhlman and Huang, 2008). The LSL-

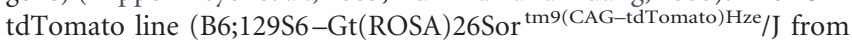
The Jackson Laboratory; donated by the Allen Brain Institute, Seattle, WA) has lox-flanked STOP (LSL) cassette upstream of the tdTomato sequence inserted in their genome and is used as a conditional reporter line. When the PV-Cre line is crossed with the LSL-tdTomato line, Cremediated recombination excises the STOP cassette upstream of the tdTomato gene yielding tdTomato expression. The offspring of this breeding was used for the fluorescent visualization of PV interneurons. By adulthood, $>95 \%$ of $\mathrm{PV}^{+}$cells express tdTomato, and all tdTomato cells express PV (Fig. 1B), consistent with previously published results for these mice (Hippenmeyer et al., 2005; Kuhlman and Huang, 2008).

Maintenance of all animal and surgical procedures used were approved by the institutional animal care and usage committee at Stony Brook University and were in line with the guidelines established by the National Institutes of Health. We used both male and female mice for experiments.

\section{Electrophysiological recording}

Recording solutions, acute brain slicing, targeting of layers $2 / 3$ interneurons, and recording of membrane properties were essentially performed as described previously in detail (Watanabe et al., 2005; Helm et al., 2013). Briefly, the artificial CSF (ACSF) bath solution consisted of the following (in mM): $125 \mathrm{NaCl}, 2.5 \mathrm{KCl}, 25$ glucose, $25 \mathrm{NaHCO}_{3}, 1.25$ $\mathrm{NaH}_{2} \mathrm{PO}_{4}, 2 \mathrm{CaCl}_{2}, 1.2 \mathrm{MgCl}_{2}, 1.3 \mathrm{Na}$-ascorbate, and $0.6 \mathrm{Na}$-pyruvate (saturated with $95 \% \mathrm{O}_{2} / 5 \% \mathrm{CO}_{2}$ under all conditions). Our internal solution contained the following (in $\mathrm{mM}$ ): $135 \mathrm{~K}$-gluconate, $4.3 \mathrm{KCl}, 2$ $\mathrm{NaCl}, 10$ HEPES, 20 phosphocreatine, $4 \mathrm{Mg}$-ATP, and $0.3 \mathrm{GTP}, \mathrm{pH} 7.3$
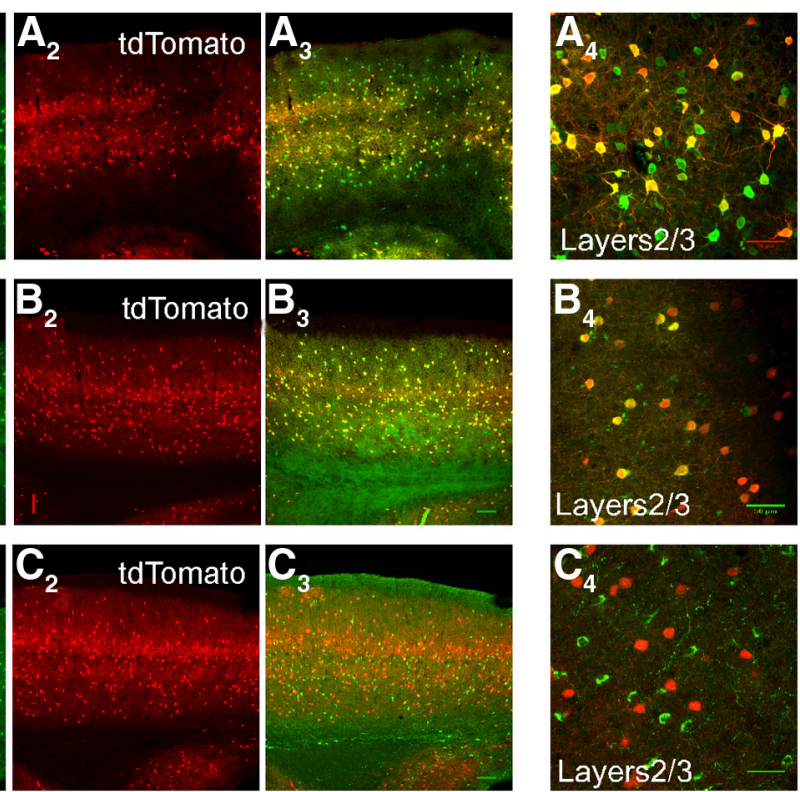

Layers $2 / 3$

Figure 1. In PVdT mice, tdTomato colocalizes with PV. Confocal images of the visual cortex from juvenile $\left(\boldsymbol{A}_{7}-\boldsymbol{A}_{4}\right)$ or adult

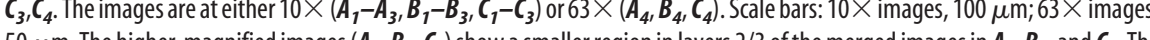
$\mu \mathrm{m}$. The higher-magnified images $\left(\boldsymbol{A}_{4}, \boldsymbol{B}_{4}, \boldsymbol{C}_{4}\right)$ show a smaller region in layers $2 / 3$ of the merged images in $\boldsymbol{A}_{3}, \boldsymbol{B}_{3}$, and $\boldsymbol{C}_{3}$. The specificity of the PV and SOM antibodies has been verified (Akgul and Wollmuth, 2010). Merged images show either colocalization of PV and tdTomato $\left(\boldsymbol{A}_{3}, \boldsymbol{A}_{4}\right.$ and $\left.\boldsymbol{B}_{3}, \boldsymbol{B}_{4}\right)$ or lack of overlap between SOM and tdTomato $\left(\boldsymbol{C}_{3}, \boldsymbol{C}_{4}\right)$. cluded in the internal solution for postfixation neuronal labeling.

For RNase-sensitive experiments, we prepared the internal solution under RNase-free conditions, including using nuclease-free water and opening chemicals for the first time. The internal solution was filtered with a sterile filter $(0.2 \mu \mathrm{m})$. Isolated mouse brain RNA was incubated overnight at $37^{\circ} \mathrm{C}$ with a sample of the internal solution, nuclease-free water, or RNase A containing buffer separately, as controls. The RNA was run on agarose gel to confirm that the internal solution was RNase-free. Internal solutions passing this quality control were aliquoted and stored at $-20^{\circ} \mathrm{C}$ for future use.

Acute slice preparation. Mice between postnatal day 15 (P15) and P17 were anesthetized with isoflurane and then decapitated. P56-P65 mice were anesthetized with ketamine $(0.12 \mathrm{cc} / 100 \mathrm{~g})$ and xylazine $(0.05 \mathrm{cc} /$ $100 \mathrm{~g})$ and then transcardially perfused with ice-cold ACSF with kynurenic acid $(200 \mathrm{mg} / \mathrm{ml})$ before decapitation. The brains of both ages were dissected out in the same solution. Coronal slices were collected from each blocked hemisphere using a vibratome (Leica). Slice collection began $0.5-1 \mathrm{~mm}$ rostral to the caudal cortical surface and totaled four 300 $\mu \mathrm{m}$ slices per hemisphere. Slices were placed into oxygenated ACSF at $32^{\circ} \mathrm{C}$ for $15-30 \mathrm{~min}$ and then incubated at room temperature until experimentation.

Electrophysiology. An EPC 10 USB amplifier with PatchMaster software (HEKA) was used to record membrane potentials or currents at $32-34^{\circ} \mathrm{C}$. Recordings were sampled at $20 \mathrm{kHz}$ and low-pass filtered using a four-pole Bessel filter at $10 \mathrm{kHz}$. After achieving the whole-cell mode, resting membrane potentials $\left(V_{\mathrm{m}}\right)$ were measured in current clamp. The amplifier mode was changed to voltage clamp, and the baseline holding potential was set to $-70 \mathrm{mV}$. Pipette series resistance, neuronal membrane resistance, and neuronal membrane capacitance $\left(C_{\mathrm{m}}\right)$ were monitored at the start and regularly throughout the experiment using the LOCKIN Sine+DC protocol from HEKA. The amplifier was then switched to current-clamp mode, and the current was adjusted to bring the reported membrane potential to approximately $-70 \mathrm{mV}$. APs were evoked using a series of depolarizing pulses of $1 \mathrm{~s}$ duration each, with $5 \mathrm{~s}$ between each stimulus. The amplifier was subsequently switched to voltage-clamp mode with the holding potential set to $-70 \mathrm{mV}$ to record 
Table 1. Primer list for single-cell RT-PCR

\begin{tabular}{|c|c|c|c|c|c|}
\hline$\overline{\text { Marker }}$ & GenBank Accession number & First PCR primers & Size (bp) & Second PCR primers & Size (bp) \\
\hline GAD65 & NM_08078.2 & $\begin{array}{l}\text { Sense, 99: CCAAAAGTTCACGGGCGG } \\
\text { Antisense } 454 \cdot \text { TCCTCCAGATTTGCGGTTG }^{a}\end{array}$ & 375 & $\begin{array}{l}\text { Sense, 219: CACCTGCGACCAAAAACCCT } \\
\text { Antisense 447· GATITTGCGGTIGGTTGCC }\end{array}$ & 248 \\
\hline GAD67 & NM_008077.4 & $\begin{array}{l}\text { Sense, 83: ATGATACTTGGTGTGGCGTAGC }{ }^{a} \\
\text { Antisense, 314: GTTTGCTCCTCCCCGTTCTTAG }\end{array}$ & 253 & $\begin{array}{l}\text { Sense, 159: CAATAGCCTGGAAGAGAAGAGTCG177 } \\
\text { Antisense, 314: GTTTGCTCCTCCCCGTTCTTAG }\end{array}$ & 177 \\
\hline PV & NM_013645.3 & $\begin{array}{l}\text { Sense, 67: GATAGGAGCCTTTGCTGCTG } \\
\text { Antisense, 347: CAGCCACCAGAGTGGAGAAT }\end{array}$ & 281 & $\begin{array}{l}\text { Sense, 124: GGGCCTGAAGAAAAAGAACC } \\
\text { Antisense, same as the first PCR }\end{array}$ & 224 \\
\hline SAP97 & NM_007862.3 & $\begin{array}{l}\text { Sense, 481: AAGGCAAATCCTCCTCCAGT } \\
\text { Antisense, 1445: ACCGATATGATGCGATCTCC }\end{array}$ & 964 & $\begin{array}{l}\text { Sense, same as the first PCR } \\
\text { Antisense, } 719 \text { : TTTACCCGCAATCTTCCATC }\end{array}$ & 239 \\
\hline 3' UTR & NM_007862.3 & $\begin{array}{l}\text { Sense, GGTTTGGCCAGTGTATTAGCTC } \\
\text { Antisense, GAGCTAATACACTGGCCAAACC }\end{array}$ & & $\begin{array}{l}\text { Sense, GTCCTCCACACTGACACAGATC } \\
\text { Antisense, CAGAGCCGTAACCACAGTGTAC }\end{array}$ & 380 \\
\hline VGlut1 & NM_182993.2 & $\begin{array}{l}\text { Sense, 124: CCCTTAGAACGGAGTCGGCT } \\
\text { Antisense, 697: } \text { TATCCGACCACCAGCAGCAG }^{b}\end{array}$ & 593 & $\begin{array}{l}\text { Sense, 148: ACGACAGCCTTTTGCGGTTC }{ }^{b} \\
\text { Antisense, 495: CAAAGTAGGCGGGCTGAGAG }\end{array}$ & 367 \\
\hline
\end{tabular}

Position 1 is the first base of the start codon. The SAP97 primers are pan-SAP97 recognizing both the $\alpha$ and $\beta$ isoforms.

EPSCs. Miniature EPSCs (mEPSCs) were recorded in the standard ACSF (containing $\mathrm{Mg}^{2+}$ ) plus the $\mathrm{Na}_{\mathrm{v}}$ blocker tetrodotoxin (TTX) $(1 \mu \mathrm{M})$ to block APs and the $\mathrm{GABA}_{\mathrm{A}}$ noncompetitive antagonist picrotoxin (50 $\mu \mathrm{M})$ to block inhibitory synaptic responses. For selected recordings, 6-cyano-7-nitroquinoxaline-2,3-dione (CNQX) $(10 \mu \mathrm{M})$ was applied to confirm that mEPSCs were mediated by AMPARs. In all instances tested, mEPSCs were completely blocked by CNQX (data not shown) (Helm et al., 2013).

Analysis of membrane and synaptic properties. Analysis of firing patterns, subthreshold membrane properties, AP shape, and mEPSPs were performed as described by Helm et al. (2013). Analysis of membrane properties was done in either PatchMaster or IGOR Pro (Wavemetrics). To compare AP firing patterns, we initially analyzed the voltage record that contained $\sim 30 \mathrm{APs}$, which corresponds to firing APs at $30 \mathrm{~Hz}$ (the current step was $1 \mathrm{~s}$ in duration), the low range of the gamma frequency (Jagadeesh et al., 1992).

mEPSCs were digitally refiltered at $2 \mathrm{kHz}$ before being analyzed using the MiniAnalysis program (Synaptosoft) (Helm et al., 2013). Briefly, amplitude threshold levels were set at 5 pA. Recordings with baseline noise root mean squared $>5 \mathrm{pA}$ were not included in analysis. Segments with high levels of noise that obscured the baseline were omitted, and event detection resumed when the baseline leveled. Our approach to measuring mEPSCs yielded a false-negative rate of $\sim 6 \%$ and a falsepositive rate of $\sim 2 \%$ (visual inspection of five randomly selected 100 event segments). We also measured access resistance, always $<10 \mathrm{M} \Omega$, for each individual interneuron before recording mEPSCs. Average access resistance values, reported in the appropriate figure legend, were not statistically different between groups.

\section{Single-cell RT-PCR}

Single-cell RT-PCR was performed according to published methods (Toledo-Rodriguez and Markram, 2007). Briefly, after a recording session, cytoplasm of the recorded neuron was partially aspirated into the recording pipette. Then, by applying positive pressure, the pipette contents were released into a RNase-free microcentrifuge tube $(8 \mu \mathrm{l})$ containing $3 \mu \mathrm{l}$ of nuclease-free water (Ambion), $2 \mu \mathrm{l}$ RNase inhibitor (40 $\mathrm{U} / \mu \mathrm{l}$; Invitrogen), and $1 \mu \mathrm{l}$ of random hexanucleotides $(3 \mathrm{mg} / \mathrm{ml}$; Invitrogen). The mixture was sonicated in icy water for $5 \mathrm{~min}$ and then heated to $70^{\circ} \mathrm{C}$ for $10 \mathrm{~min}$. After a brief incubation (1-2 min) on ice, $4 \mu \mathrm{l}$ of $5 \times$ first-strand buffer (250 mm Tris- $\mathrm{HCl}, 375 \mathrm{~mm} \mathrm{KCl}$, and $15 \mathrm{~mm} \mathrm{MgCl}), 0.5$ $\mu \mathrm{l}$ DTT $(0.1 \mathrm{M})$, and $1 \mu \mathrm{l}$ of mixed deoxynucleotide triphosphates (dNTPs; $10 \mathrm{~mm}$ [SCAP]; Invitrogen) were added and the mixture was incubated $10 \mathrm{~min}$ at room temperature before adding $1 \mu \mathrm{l}$ of SuperScript II reverse transcriptase (RT-II; $2 \mathrm{U} / \mathrm{ml}$; Invitrogen). The reverse transcription reaction was performed at $42^{\circ} \mathrm{C}$ for $60-90$ min to synthesize cDNA. The reaction solution was incubated then at $95^{\circ} \mathrm{C}$ for $5 \mathrm{~min}$ to deactivate RT-II and remove the RNA strand from the RNA-DNA hybrid. For PCR, the reaction mixtures contained $2.0 \mathrm{mM} \mathrm{MgCl}_{2}, 0.5 \mathrm{~mm}$ each of the dNTPs (Invitrogen), 0.8-1.0 mu primers, $2.5 \mathrm{U}$ of TaqDNA polymerase (Invitrogen), $5 \mu \mathrm{l}$ of $10 \times$ buffer, $2 \mu \mathrm{l}$ of cDNA template from the single- cell RT reaction, and primers for each glutamate decarboxylase 67 (GAD67), GAD65, PV, SAP97, and vesicular glutamate transporter 1 (VGluT1) (Table 1). Each reaction went through 35 cycles of the first round of PCR, followed by additional 35 cycles of the second round of PCR with the nested primer pairs under the same conditions. The products were visualized by ethidium bromide staining after electrophoresis in $2 \%$ agarose gels. Primers were tested on the cDNA made with dilutions of RNA ( 2 pg to $100 \mathrm{ng}$ ) isolated from mouse cortex.

\section{Virus injection}

Recombinant virus production. In neurons, SAP97 is expressed in two spliced isoforms, $\alpha$ and $\beta$, that differ in their $\mathrm{N}$ terminus (Schlüter et al., 2006). Because of concerns about the size limitations for packaging into the viral construct, we chose to exogenously express the $\alpha$ isoform because it is $\sim 300$ bp smaller than the $\beta$ isoform.

$\alpha$-SAP97 with an enhanced green fluorescent protein (EGFP) gene at the $\mathrm{C}$ terminus was cloned into a plasmid carrying a FLEX switch (Atasoy et al., 2008). The FLEX switch was constructed with two pairs of lox cassettes (loxP/lox2272) facing each other. The vector and the gene of interest were digested with SpeI restriction enzyme. During cloning into the FLEX switch vector, the orientation of the gene was verified with sequence analysis. The FLEX switch with $\alpha$-SAP97-EGFP in reverse orientation was digested with BamH1/EcoRI (BamHI site in $\alpha$-SAP97 was removed via site-directed mutagenesis) and ligated into a vector (supplied by Z. J. Huang, Cold Spring Harbor Laboratory, Cold Spring Harbor, NY) containing the CMV promoter, SV40 poly(A) sequence, and two inverted terminal repeats required for recombinant adenoassociated virus (AAV2/9) production. To verify the fidelity of the construct, HEK 293 cells were transfected using Fugene HD (Roche Diagnostics) according to the instructions of the manufacturer. $\alpha$-SAP97-EGFP_AAV vectors were cotransfected with Cre in pcDNA3.1 vector (Invitrogen) or with empty pcDNA3.1. After $48 \mathrm{~h}$, cells were imaged for EGFP fluorescence. FLEX-rev- $\alpha$-SAP97-EGFP_AAV was produced by the University of North Caroline Gene Therapy Program Vector Core.

Stereotaxic injections into mouse visual cortex. Mice were anesthetized with ketamine $(100 \mu \mathrm{g} / \mathrm{g}$ body weight $)$ and xylazine $(10 \mu \mathrm{g} / \mathrm{g}$ body weight) and were placed into a stereotaxic apparatus (Stoelting). The hair on the head was removed, and the skin was wiped with $70 \% \mathrm{EtOH}$. The skull was exposed via a small incision, and a small hole was opened with a dental drill. The following stereotaxic coordinates were used for visual cortex: $-1.0 \mathrm{~mm}$ anterior to lambda; $2.5-3.0 \mathrm{~mm}$ lateral from the midline; $0.5 \mathrm{~mm}$ down from the dural surface. A $1 \mu \mathrm{l}$ Hamilton, flat-tip syringe was mounted, and $0.5 \mu \mathrm{l}$ of AAV was injected at a rate of 0.25 $\mu \mathrm{l} / \mathrm{min}$ into the visual cortex. The syringe was withdrawn $5 \mathrm{~min}$ after the final injection. For injection, $\alpha$-SAP97-EGFP_AAV titer was $1.8 \times 10^{12}$ $\mathrm{GC} / \mathrm{ml}$. 


\section{Morphology}

Biocytin labeling. The slices were fixed in $4 \%$ paraformaldehyde in PBS overnight. After they were permeabilized using 1\% Triton X-100 in PBS for $1 \mathrm{~h}$, the slices were stained with Texas Red Streptavidin or DyLight649 Streptavidin (1:2000) in $0.1 \%$ Triton X-100 in PBS for $3 \mathrm{~h}$ at room temperature or overnight at $4^{\circ} \mathrm{C}$. Stained slices were washed three times for at least 5 minutes each in PBS before mounting on a glass slide for microscopy. Labeled neurons were imaged using a confocal microscope and software (Olympus Fluoview).

Tracing. Confocal images of interneurons were traced in Imaris (Bitplane). Imaris was used to measure the number of primary dendrites, branches, and terminal points and to perform Sholl analysis. NIH ImageJ (Wayne Rasband, National Institutes of Health, Bethesda, MD) was used to generate a projection image. The vertical and horizontal extent of soma and dendritic arbor and distance from soma to pia were measured in the projection image.

Sholl analyses. The number of intersections at concentric circles (20 $\mu \mathrm{m}$ apart) was counted for each cell with the Sholl analysis component of Imaris (Sholl, 1953).

\section{Immunohistochemistry}

The procedure for immunohistochemistry including characterizing antibodies was described in detail previously (Akgul and Wollmuth, 2010). We used the primary antibodies rabbit polyclonal anti-PV (Abcam) and rat monoclonal anti-SOM (Millipore Bioscience Research Reagents). As secondary antibodies, we used fluorescent Alexa Fluor 488-conjugated anti-rabbit and anti-rat IgG (Invitrogen). Images were taken and analyzed with an Olympus Fluoview FV1000 confocal microscope.

\section{Statistical analyses}

Statistical analysis of experimental measures including curve fitting was performed in IGOR Pro (Wavemetrics) or Excel (Microsoft). Results are reported as mean \pm SEM. A Student's $t$ test was used to test for statistical differences usually using the SAP97-nonexpressing $\left(\mathrm{SAP}^{-} 7^{-}\right.$) group as a reference. Significance was assumed if $p<0.05$. For mEPSCs, we used two approaches to determine significant differences. First, 500 mEPSCs were randomly sampled from each cell and combined for each subgroup, and the Komogorov-Smirnov (KS) test $(\alpha=0.05)$ was used to test for significance. The resulting $p$ value was adjusted for multiple pairs using the Bonferroni's correction. Second, PV interneurons show a high frequency of synaptic events, typically $>20 \mathrm{~Hz}$, and we recorded mEPSCs for long periods (1-2 min). At high event frequencies and sample numbers, the Poisson distribution can be approximated by the normal distribution. Therefore, we averaged mEPSC measurements for each cell (the average number of events, typically $>1000$, for each group is indicated in appropriate figure legend) and used a Student's $t$ test to test for statistical differences using the SAP97 ${ }^{-}$group as a reference. The $t$ test results are more stringent overall than the KS test, so highlights the strongest differences. Statistical analysis was performed in IGOR Pro (Wavemetrics).

\section{Results \\ $\mathrm{PV}^{+}$interneurons in layers $2 / 3$ of the visual cortex from juvenile and adult PV-tdTomato mice}

In our study, we took advantage of a transgenic line (PV-Cre) that expresses Cre recombinase under the control of the endogenous PV promoter (Hippenmeyer et al., 2005). We crossed PVCre mice with another line that carries tdTomato gene expressed conditionally in the presence of Cre recombinase (see Materials and Methods). As a result, their offspring, PV-tdTomato (PVdT) mice, express tdTomato in PV interneurons.

To confirm cell-type-specific expression of tdTomato, we stained the visual cortex from juvenile and adult PVdT mice with $\mathrm{PV}$ antibody. Figure 1 shows confocal images of tissue sections, encompassing the visual cortex, from juvenile (P16; Fig. $1 A_{1}-A_{4}$ ) or adult (Fig. $1 B_{1}-B_{4}$ ) mice labeled with PV antibody (green, first column) and visualized for tdTomato expression (red, second column). The third and fourth columns show merged images. In juvenile mice, PV and tdTomato signals primarily overlap (Fig. $\left.1 A_{3}, A_{4}\right)$. As seen in Figure $1 A_{4}$, which is an enlarged image, a small number of $\mathrm{PV}^{+}$cells lack the tdTomato signal. Presumably, the difference between $\mathrm{PV}^{+}$label and tdTomato signals in juvenile mice results from the time window between the activation of the $\mathrm{PV}$ promoter, which is turned on in the mouse visual cortex at approximately P14 (Kawaguchi, 1995; Gonchar et al., 2007), and the successful Cre/lox recombination and subsequent tdTomato expression. Consistent with this idea, in adults (Fig. $1 B_{3}, B_{4}$ ), almost all (>95\%) $\mathrm{PV}^{+}$interneurons express tdTomato. To further verify the cell-type specificity of tdTomato expression, we stained the visual cortex of adult PVdT mice with antibody to somatostatin (SOM). $\mathrm{SOM}^{+}$interneurons are the second largest interneuron population and are non-overlapping with $\mathrm{PV}^{+}$interneurons in the visual cortex (Kubota and Kawaguchi, 1994; Gonchar et al., 2007). Figure $1 C_{1}-C_{4}$ shows no overlap between $\mathrm{SOM}^{+}$label and tdTomato signal, confirming the cell-type specificity of tdTomato expression in PV interneurons.

\section{The expression of SAP97 in a subset of juvenile and adult PV interneurons is developmentally regulated}

To address the functional significance of SAP97 expression in PV interneurons in the visual cortex, we initially used single-cell RTPCR to determine the gene expression profiles of recorded neurons. PV interneurons in layers $2 / 3$ of the visual cortex in acute slices were identified by tdTomato fluorescence, patched in the whole-cell configuration, and stimulated to confirm fast-spiking firing patterns. We recorded the passive and active membrane properties as well as mEPSCs from P15-P17 (juvenile) and P56P65 (adult) PVdT mice. Once the recording protocol was completed, we harvested cell contents for single-cell RT-PCR (see Materials and Methods).

We used gene-specific primers (Table 1) to assay for expression of mouse PV, SAP97, GAD65, GAD67, and VGluT1. The SAP97 primers recognize both $\alpha$ and $\beta$ isoforms. We first assayed for PV expression to verify the quality of mRNA and to ensure that negative results for SAP97 were not false negatives. Therefore, we included in subsequent analysis only those samples positive for PV. The expression of GAD67 and GAD65, which are expressed in all GABAergic interneurons (Cauli et al., 2000; Vullhorst et al., 2009), were used as positive controls. VGluT1, which is a pyramidal neuron marker (Fremeau et al., 2001), was also tested on each sample to rule out possible nonspecific RNA contamination.

In the juvenile visual cortex, SAP97 mRNA was detected in a majority of interneurons ( 12 of 19 , or $63 \%$ PV interneurons; Fig. $\left.2 A_{1}, A_{2}\right)$. In contrast, SAP97 mRNA was detected in a much smaller fraction of interneurons in the adult visual cortex ( 6 of 21, or $29 \%$ PV interneurons; Fig. $2 A_{3}, A_{4}$ ). This developmental expression of SAP97, in which it is expressed in a higher percentage of juvenile than adult PV interneurons, is consistent with previous results (Akgul and Wollmuth, 2010) (see also Discussion).

\section{$\mathrm{SAP}^{+}{ }^{+}$and $\mathrm{SAP}^{-}{ }^{-} \mathrm{PV}$ interneurons show distinct membrane properties}

For functional analysis, we generally sorted PV interneurons into subsets based on SAP97 mRNA expression, either SAP97 ${ }^{+}$or SAP97 ${ }^{-}$(Fig. $2 A_{1}-A_{4}$ ). Figure $2 B-D$ shows representative recording traces for juvenile or adult PV interneurons either $\mathrm{SAP}^{+}{ }^{+}$or SAP97 ${ }^{-}$. The voltage traces $\left(V_{\mathrm{m}}\right)$ in Figure $2 B$ show examples of firing patterns at $\sim 30 \mathrm{~Hz}$, at the low end of gamma frequency (Jagadeesh et al., 1992), along with the associated current injections $\left(I_{\mathrm{m}}\right)$. The voltage traces in Figure $2 C$ show the first 


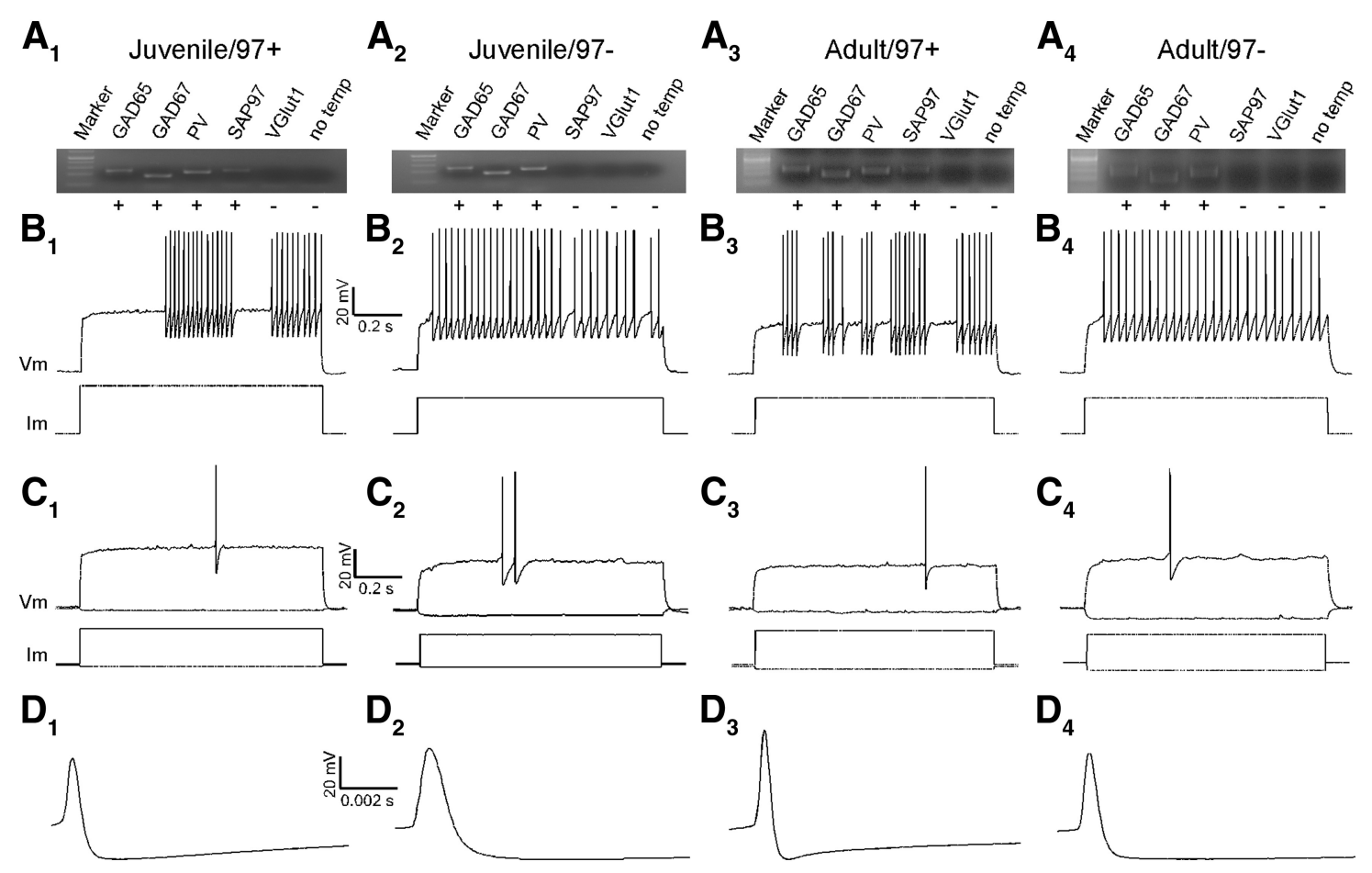

Figure 2. $\mathrm{SAP} 97^{+} \mathrm{PV}$ interneurons display distinct membrane properties from those not expressing SAP97. Analysis of membrane properties in juvenile PV interneurons either expressing (first column, Juvenile/97+) or not expressing (second column, Juvenile/97-) SAP97 or adult PV interneurons either expressing (third column, Adult/97+) or not expressing (last column, Adult/97-) SAP97. Each column represents the results from the same interneuron. $A_{1}-A_{4}$ Gene expression profiles of individual interneurons. GAD67 and GAD65 are GABAergicinterneuron markers, and PVis PV interneuron marker. GAD67 and GAD65 are used as positive controls. VGluT1 and no template (no temp) lanes are negative controls. $\boldsymbol{B}_{1}-\boldsymbol{B}_{4}$, Voltage traces $\left(V_{\mathrm{m}}\right)$ of individual interneurons firing at $\sim 30 \mathrm{~Hz}$. The depolarizing currents $\left(I_{\mathrm{m}}\right)$ to elicit $30 \mathrm{~Hz}$ firing are $790,310,340$, and $200 \mathrm{pA}$, respectively. $\boldsymbol{C}_{1}-\boldsymbol{C}_{4}$, Voltage traces $\left(V_{\mathrm{m}}\right)$ for the hyperpolarized membrane potential and the first AP in response to rheobase current are shown along with the injected current traces. Rheobase currents are 720, 190, 200, and $150 \mathrm{pA}$, respectively. $\boldsymbol{D}_{\mathbf{1}}-\boldsymbol{D}_{4}$, The rheobase APs are expanded (10 ms total time) to highlight differences in AP shape.

AP in response to rheobase current. These APs are magnified in Figure $2 D$.

In terms of membrane properties, PV interneurons in layers 2/3 undergo significant developmental changes (Goldberg et al. 2011; Lazarus and Huang 2011). We also observed a significant shift in membrane excitability and AP shape of PV interneurons between juvenile and adult PV interneurons (Fig. 2; Table 2). Most notable was a reduced sensitivity to current input ( $F / I$ slope: juvenile, $2.2 \pm 0.3 \mathrm{~Hz} / \mathrm{pA}$; adult, $1.2 \pm 0.1 \mathrm{~Hz} / \mathrm{pA} ; p<0.01)$, an increased input resistance $\left(R_{\mathrm{m}}\right.$ : juvenile, $106 \pm 10 \mathrm{M} \Omega$; adult, $159 \pm 12 \mathrm{M} \Omega ; p<0.001$ ), a decreased rheobase (juvenile, $384 \pm$ $46 \mathrm{pA}$; adult, $228 \pm 16 \mathrm{pA} ; p<0.01$ ), a narrowing of AP halfwidth (juvenile, $0.54 \pm 0.04 \mathrm{~ms}$; adult, $0.44 \pm 0.03 \mathrm{~ms} ; p<0.05$ ), and a reduced afterhyperpolarization (AHP) (juvenile, $-298 \pm$ $42 \mathrm{~V} / \mathrm{s}$; adult, $-213 \pm 15 \mathrm{~V} / \mathrm{s} ; p<0.05)$. In both juvenile and adult PVdT mice, membrane properties recorded from either $\mathrm{SAP}^{+}{ }^{+}$or SAP97 ${ }^{-} \mathrm{PV}$ interneurons show significant differences (Fig. 2; Table 3). Although there were developmental changes in membrane properties, these changes occur with a similar pattern in both age groups.

In terms of firing patterns, PV interneurons expressing SAP97 almost always fired with an irregular pattern lacking a uniform spacing between APs; often for juvenile (five of eight) but more typical for adult (four of five), the firing pattern could be characterized as stuttering with clusters of APs fired at high frequency separated by quiet periods (Fig. $2 B_{1}, B_{3}$ ). In contrast, SAP97 ${ }^{-} \mathrm{PV}$ interneurons fire APs in a more regular manner (Fig. $2 B_{2}, B_{4}$ ), although modest uneven spacing in APs at these moderate stimulation levels did sometimes occur (Fig. $2 B_{2}$ ). The differences in firing patterns are best represented quantitatively by the ratio of maximum to minimum interspike intervals (Max/Min ISI) (Ta-
Table 2. Passive and active membrane properties of juvenile and adult PV intemeurons

\begin{tabular}{lcc}
\hline & Juvenile & \multicolumn{1}{l}{ Adult } \\
\hline Firing pattern & & \\
Delay first AP (ms) & $462 \pm 57$ & $395 \pm 79$ \\
ISI average (ms) & $25.9 \pm 1.2$ & $24.2 \pm 1.4$ \\
Frequency adaptation & $1.03 \pm 0.12$ & $1.30 \pm 0.09^{*}$ \\
Max ISI (ms) & $109 \pm 23$ & $120 \pm 40$ \\
Min ISI (ms) & $20.3 \pm 1.3$ & $18.4 \pm 1.3$ \\
Max/Min ISI & $6.4 \pm 1.7$ & $7.6 \pm 2.6$ \\
CV frequency & $0.20 \pm 0.02$ & $0.20 \pm 0.03$ \\
F/l slope (Hz/pA) & $2.2 \pm 0.3$ & $1.2 \pm 0.1^{* * *}$ \\
Passive & & \\
$V_{\mathrm{m}}$ (mV) & $-86 \pm 1.4$ & $-87 \pm 1.2$ \\
$R_{\mathrm{m}}$ (MS) & $106 \pm 10$ & $159 \pm 12^{* * *}$ \\
Rheobase (pA) & $384 \pm 46$ & $228 \pm 16^{* *}$ \\
AP shape & & \\
AP threshold (mV) & $-46.3 \pm 1.5$ & $-49.6 \pm 1.0^{*}$ \\
AP 10-90\% rise (ms) & $0.27 \pm 0.01$ & $0.25 \pm 0.01$ \\
AP half-width (ms) & $0.54 \pm 0.04$ & $0.44 \pm 0.03^{*}$ \\
AHP peak (mV) & $-24.7 \pm 0.6$ & $-23.8 \pm 1.0$ \\
AHP latency (ms) & $2.2 \pm 0.4$ & $1.4 \pm 0.2^{*}$ \\
AHP area (V/s) & $-298 \pm 42$ & $-213 \pm 15^{*}$ \\
Number of interneurons & 14 & 20 \\
\hline
\end{tabular}

Juvenile (P15-P17) or adult (P56-P65) PV interneurons are characterized by firing pattern, passive membrane properties, and AP shape (see Materials and Methods). Values shown as mean \pm SEM. Attest was used to determine whether the value for juvenile was significantly different from that for adult $\left({ }^{*} p<0.05\right.$, ${ }^{* *} p<0.01$, and ${ }^{* * *} p<$ $0.001)$. Note that the number of recorded interneurons is less than sampled for mRNA (19, juvenile; 21 , adult) because not all interneurons sampled provided stable AP recordings.

ble 3). The Max/Min ISI ratio of SAP97 ${ }^{+}$interneurons (juvenile, $9.2 \pm 2.6$; adult, $20.2 \pm 7.4$ ) is significantly greater than that for SAP97 ${ }^{-}$interneurons at the same age (juvenile, $2.8 \pm 0.5, p<$ 0.05 ; adult, $3.1 \pm 0.8, p<0.05)$. Furthermore, SAP9 ${ }^{+} \mathrm{PV}$ in- 
Table 3. Passive and active membrane properties of juvenile and adult PV interneurons expressing, not expressing, or exogenously expressing SAP97

\begin{tabular}{|c|c|c|c|c|c|}
\hline & \multicolumn{2}{|l|}{ Juvenile } & \multicolumn{3}{|l|}{ Adult } \\
\hline & SAP97 $^{+}$ & SAP97 $^{-}$ & $\mathrm{SAP} 7^{+}$ & SAP97 $^{-}$ & SAP97egfp \\
\hline \multicolumn{6}{|l|}{ Firing pattern } \\
\hline Delay first AP (ms) & $440 \pm 80$ & $500 \pm 80$ & $510 \pm 170$ & $360 \pm 90$ & $276 \pm 125$ \\
\hline ISI average (ms) & $28.9 \pm 1.2$ & $29.5 \pm 1.5$ & $26.9 \pm 2.6$ & $27.1 \pm 2.2$ & $26.1 \pm 3.0$ \\
\hline Frequency adaptation & $0.96 \pm 0.20$ & $1.12 \pm 0.12$ & $1.42 \pm 0.23$ & $1.27 \pm 0.11$ & $0.72 \pm 0.24$ \\
\hline Max ISI (ms) & $144 \pm 35^{*}$ & $62 \pm 10$ & $308 \pm 118^{*}$ & $53 \pm 9$ & $208 \pm 46^{* *}$ \\
\hline Min ISI (ms) & $18.2 \pm 1.5^{*}$ & $23.0 \pm 1.7$ & $15.5 \pm 1.1^{*}$ & $19.4 \pm 1.7$ & $12.3 \pm 1.3^{* *}$ \\
\hline Max/Min ISI & $9.2 \pm 2.6^{*}$ & $2.8 \pm 0.5$ & $20.2 \pm 7.4^{*}$ & $3.1 \pm 0.8$ & $17.4 \pm 3.6^{* *}$ \\
\hline CV frequency & $0.22 \pm 0.04$ & $0.17 \pm 0.03$ & $0.24 \pm 0.03$ & $0.20 \pm 0.04$ & $0.28 \pm 0.02^{*}$ \\
\hline F/I slope (Hz/pA) & $1.8 \pm 0.3^{*}$ & $2.6 \pm 0.4$ & $0.9 \pm 0.05^{* \$}$ & $1.2^{\$} \pm 0.15$ & $1.01 \pm 0.11$ \\
\hline \multicolumn{6}{|l|}{ Passive } \\
\hline$V_{m}(m V)$ & $-85 \pm 1.8^{*}$ & $-90 \pm 1.7$ & $-85 \pm 1.7$ & $-88 \pm 1.5$ & $-86 \pm 2.0$ \\
\hline$R_{\mathrm{m}}(\mathrm{M} \Omega)$ & $88 \pm 9.7^{* *}$ & $130 \pm 13$ & $118 \pm 13^{* * \$}$ & $173 \pm 14^{\$}$ & $110 \pm 15^{* *}$ \\
\hline Rheobase (pA) & $450 \pm 66^{*}$ & $290 \pm 40$ & $270 \pm 10^{* \$}$ & $215 \pm 20$ & $346 \pm 62^{*}$ \\
\hline \multicolumn{6}{|l|}{ AP shape } \\
\hline AP threshold (mV) & $-45.6 \pm 2.5$ & $-47.3 \pm 1.2$ & $-49.3 \pm 1.6$ & $-49.7 \pm 1.5$ & $-53.4 \pm 2.1$ \\
\hline AP $10-90 \%$ rise (ms) & $0.25 \pm 0.01$ & $0.29 \pm 0.01$ & $0.21 \pm 0.01^{*}$ & $0.26 \pm 0.02$ & $0.20 \pm 0.01^{* *}$ \\
\hline AP half-width (ms) & $0.48 \pm 0.02^{*}$ & $0.63 \pm 0.08$ & $0.37 \pm 0.02^{* \$}$ & $0.46 \pm 0.04^{\$}$ & $0.32 \pm 0.01^{* * *}$ \\
\hline AHP peak (mV) & $-25.3 \pm 0.6$ & $-23.9 \pm 1.0$ & $-24.5 \pm 1.5$ & $-23.6 \pm 1.0$ & $-23.6 \pm 1.5$ \\
\hline AHP latency (ms) & $1.7 \pm 0.1$ & $3.0 \pm 0.9$ & $1.1 \pm 0.1^{* \$}$ & $1.5 \pm 0.2$ & $0.8 \pm 0.04^{* *}$ \\
\hline AHP area (V/s) & $-210 \pm 20^{* *}$ & $-420 \pm 70$ & $-140 \pm 10^{* * * \$}$ & $-239 \pm 15^{5}$ & $-137 \pm 10^{* * *}$ \\
\hline Number of interneurons & 8 & 6 & 5 & 15 & 8 \\
\hline
\end{tabular}

Juvenile (P15-P17) or adult (P56-P65) PV interneurons are characterized by firing pattern, passive membrane properties, and AP shape (see Materials and Methods). Values shown as mean \pm SEM. At test was used to determine whether the value for SAP97 ${ }^{+}$or SAP97egfp were significantly different from that for SAP97 ${ }^{-}$within the same age $\left({ }^{*} p<0.05,{ }^{* *} p<0.01\right.$, and $\left.{ }^{* * *} p<0.001\right)$ or between different ages within SAP97 ${ }^{-}$or $S A P 97^{+}\left({ }^{\lessgtr} p<0.05\right)$.

terneurons fired spikes more frequently as manifested as a decrease in minimum interspike interval (Min ISI) (juvenile, 18.2 \pm 1.5; adult, $15.5 \pm 1.1$ ) compared with SAP97 ${ }^{-}$interneurons (juvenile, $23.0 \pm 1.7, p<0.05$; adult, $19.4 \pm 1.7, p<0.05$ ).

$\mathrm{SAP}^{+}{ }^{+}$and SAP97 ${ }^{-} \mathrm{PV}$ interneurons also show significant differences in terms of passive membrane properties and AP shape (Fig. 2C,D; Table 3). For example, SAP97 ${ }^{+}$PV interneurons have a lower $R_{\mathrm{m}}$ (juvenile, $88 \pm 9.7 \mathrm{M} \Omega$; adult, $118 \pm 13$ $\mathrm{M} \Omega$ ) (Fig. $2 C_{1}, C_{3}$ ) than SAP97 ${ }^{-}$interneurons (juvenile, $130 \pm$ $13 \mathrm{M} \Omega, p<0.01$; adult, $173 \pm 14 \mathrm{M} \Omega, p<0.01$ ) (Fig. $2 C_{2}, C_{4}$ ). Similarly, the rheobase current is higher for SAP97 ${ }^{+} \mathrm{PV}$ interneurons (juvenile, $450 \pm 66 \mathrm{pA}$; adult, $270 \pm 10 \mathrm{pA}$ ) than that for SAP97 ${ }^{-}$interneurons (juvenile, $290 \pm 40 \mathrm{pA}, p<0.05$; adult, $215 \pm 20 \mathrm{pA}, p<0.05)$. In terms of AP shape, SAP97 ${ }^{+} \mathrm{PV}$ interneurons have significantly smaller AHP (juvenile, $-210 \pm$ $20 \mathrm{~V} / \mathrm{s}$; adult, $140 \pm 10 \mathrm{~V} / \mathrm{s}$ ) (Fig. $2 C_{1}, C_{3}$ ) and a narrower AP half-width (juvenile, $0.48 \pm 0.02 \mathrm{~ms}$; adult, $0.37 \pm 0.02 \mathrm{~ms}$ ) (Fig. $2 D_{1}, D_{3}$ ) than those of SAP97 ${ }^{-}$interneurons (AHP: juvenile, $-420 \pm 70 \mathrm{~V} / \mathrm{s}, p<0.01$; adult, $-238 \pm 15 \mathrm{~V} / \mathrm{s}, p<0.001$; Fig. $2 C_{2}, C_{4}$; AP half-width: juvenile, $0.63 \pm 0.08 \mathrm{~ms}, p<0.05$; adult, $0.46 \pm 0.04 \mathrm{~ms}, p<0.05$; Fig. $\left.2 D_{2}, D_{4}\right)$.

In summary, the expression of SAP97 in PV interneurons is correlated with two general membrane properties: (1) a reduced excitability and (2) APs that fire at a faster rate often with long pauses at current injections just above rheobase at which firing occurs $\sim 30 \mathrm{~Hz}$. This frequency of AP firing is at the low end of the gamma frequency $(30-60 \mathrm{~Hz})$ in the visual cortex (Jagadeesh et al., 1992).

\section{PV interneurons expressing SAP97 receive a higher frequency of excitatory input}

To address whether SAP97 affects excitatory input to PV interneurons, we initially monitored AMPAR-mediated mEPSCs. Figure 3 illustrates $10 \mathrm{~s}$ and $100 \mathrm{~ms}$ current traces from representative juvenile or adult interneurons either expressing or not expressing SAP97 (Fig. 3A,B), cumulative histograms of mEPSC frequency and amplitude (Fig. $3 C$ ), and mean values for mEPSC frequency, amplitude, half-width, and decay (Fig. 3D) (see Materials and Methods).

In both juvenile and adult mice, the mEPSCs of interneurons expressing SAP97 (juvenile, $33.5 \pm 5.4 \mathrm{~Hz}, n=8$; adult, $40 \pm 6.5$ $\mathrm{Hz}, n=6$; Fig. $3 C_{1}, C_{3}, D_{1}$ ) were significantly more frequent than those not expressing SAP97 (juvenile, $20 \pm 2.7 \mathrm{~Hz}, n=5, p<$ 0.05 , $t$ test; adult, $20.1 \pm 2.0 \mathrm{~Hz}, n=13, p<0.05$; Fig. $\left.3 C_{1}, C_{4}, D_{4}\right)$. Interestingly, the overall frequency of mEPSCs does not change with development (juvenile, $28.3 \pm 4.0 \mathrm{~Hz}$; adult, $26.4 \pm 3.2 \mathrm{~Hz}$ ). Adult SAP97 ${ }^{+}$PV interneurons showed a modest but significant shift toward larger mEPSC amplitudes compared with SAP97 ${ }^{-}$ interneurons (Fig. $\left.3 C_{4}\right)(p<0.01, \mathrm{KS}$ test), whereas there is no difference in juvenile interneurons (Fig. $3 C_{2}$ ). The amplitudes of mEPSCs decreased overall by age (amplitude: juvenile, $23.2 \pm 1.6$ pA; adult, $17.5 \pm 1.0 \mathrm{pA}, p<0.05$, $t$ test; area: juvenile, $28.6 \pm 1.9$ $\mathrm{pA} / \mathrm{ms}$; adult, $18.2 \pm 1.4 \mathrm{pA} / \mathrm{ms}, p<0.05, t$ test). Conversely, the amplitudes of the synaptic events on average are not significantly different in SAP97 ${ }^{+}$and SAP97 ${ }^{-}$interneurons at either age (Fig. $3 D_{2}$ ).

Individual mEPSC events generally occurred more rapidly for interneurons expressing SAP97 (Fig. $3 B_{1}, B_{2}$ vs $B_{3}, B_{4}$ ). The halfwidth of the synaptic events on average was significantly narrower in the interneurons expressing SAP97 (Fig. $3 D_{3}$ ) because of faster decay kinetics (Fig. $3 D_{4}$ ), although these differences are significant only for adult ( $p<0.05, t$ test). There is a significant decrease in the area of synaptic events in juvenile PV interneurons expressing SAP97 compared with those not expressing SAP97 (data not shown). Hence, overall, PV interneurons expressing SAP97 show more frequent excitatory events with a trend toward these events being more rapid.

\section{Exogenous expression of SAP97 drives membrane properties of adult PV interneurons toward those of interneurons endogenously expressing SAP97}

The experiments presented so far demonstrate that SAP97 expression in PV interneurons is correlated with reduced membrane excitability, firing APs at higher rates, and more excitatory 


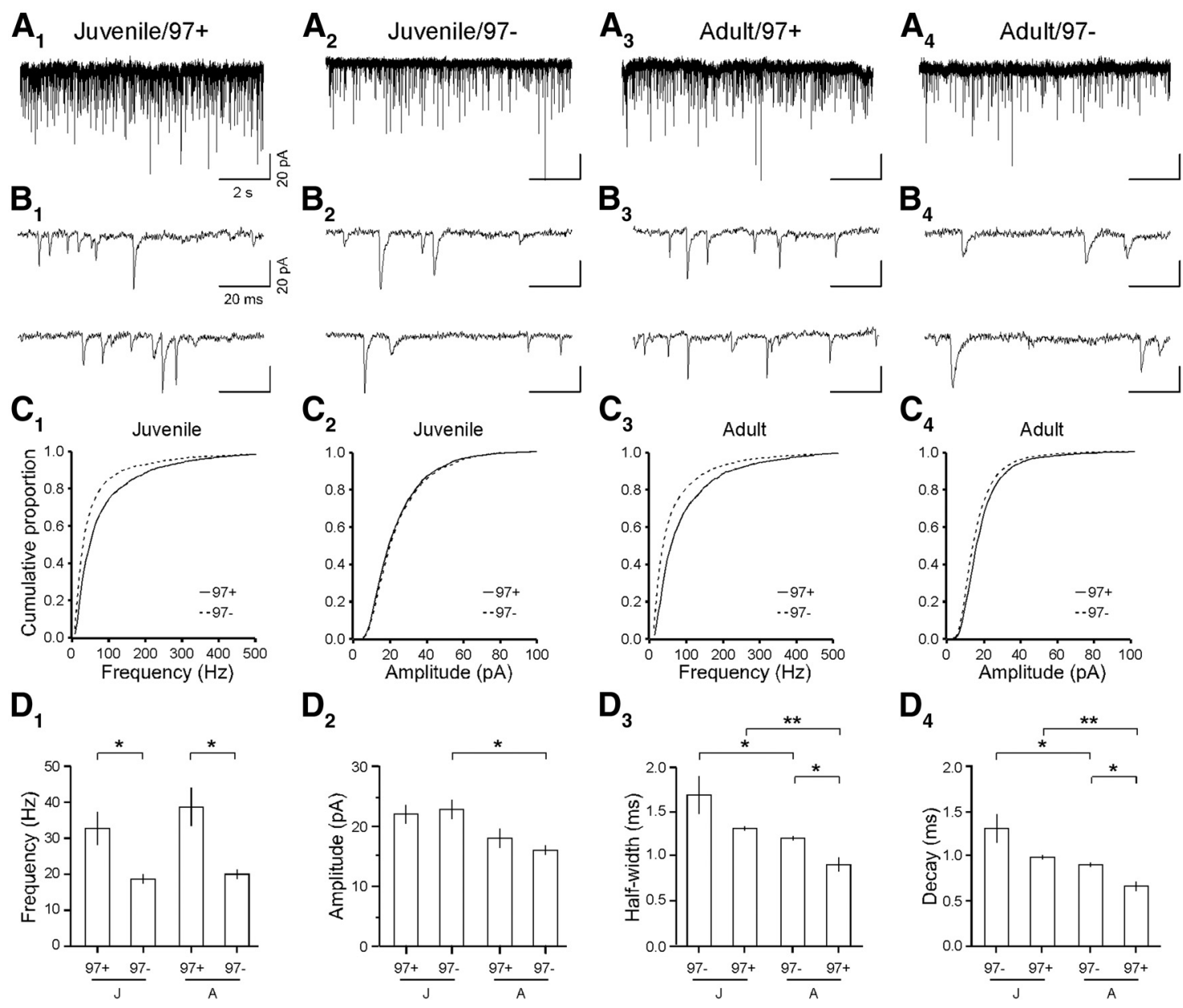

Figure 3. $\mathrm{SAP} 97^{+}$and SAP97 $-\mathrm{PV}$ interneurons receive different excitatory input. $A_{1}-A_{4}$, Representative current traces $(10 \mathrm{~s})$ from individual juvenile or adult $\mathrm{PV}$ interneurons either expressing $(97+)$ or not expressing $(97-)$ SAP97 recorded in whole-cell voltage clamp $\left(V_{\text {hold }}=-70 \mathrm{mV}\right)$ in the presence of $\mathrm{Mg}^{2+}$, TTX, and picrotoxin. $\boldsymbol{B}_{1}-\boldsymbol{B}_{4}$, Segments of the same current traces expanded to show $100 \mathrm{~ms}$ of recording. $\boldsymbol{C}_{1}-\boldsymbol{C}_{4}$, Cumulative histograms of mEPSC frequency $\left(\boldsymbol{C}_{1}, \boldsymbol{C}_{3}\right)$ and amplitude $\left(\boldsymbol{C}_{2}, \boldsymbol{C}_{4}\right)$. Continuous lines indicate SAP97+ (juvenile, $n=8$; adult, $\left.n=6\right)$, and dashed lines indicate SAP97 - (juvenile, $n=5$; adult, $n=13$ ) interneurons. mEPSC frequency distributions in both juvenile and adult SAP97 ${ }^{+}$interneurons are significantly different from those in SAP97 ${ }^{-}$ interneurons ( $p<0.01$, KS test). mEPSC amplitude distributions are significantly different between SAP97 ${ }^{+}$and SAP97 ${ }^{-}$interneurons only in adult $\left(p<0.01, \mathrm{KS}\right.$ test). $\boldsymbol{D}_{1}-\boldsymbol{D}_{4}, \mathrm{Bar}$ graphs of mEPSC frequency $\left(\boldsymbol{D}_{1}\right)$, amplitude $\left(\boldsymbol{D}_{2}\right)$, half-width $\left(\boldsymbol{D}_{3}\right)$, and decay $\left(\boldsymbol{D}_{4}\right)$. Values shown are mean \pm SEM (for details, see Materials and Methods). ${ }^{*} p<0.05,{ }^{* *} p<0.01$, Student's $t$ test. $97-$, $\mathrm{SAP} 97^{-} ; 97+, \mathrm{SAP}^{+} ; \mathrm{J}$, juvenile; $\mathrm{A}$, adult. Average access resistance and number of events for each groups are as follows: $J / 97+, 5.6 \pm 0.3 \mathrm{M} \Omega$ and $1423 \pm 145$ events; $/ / 97-, 5.4 \pm 0.4 \mathrm{M} \Omega$ and $1360 \pm 91$ events; $\mathrm{A} / 97+, 4.7 \pm 0.4 \mathrm{M} \Omega$ and $1412 \pm 124$ events; and $\mathrm{A} / 97-, 4.7 \pm 0.4 \mathrm{M} \Omega$ and $1226 \pm 67$ events.
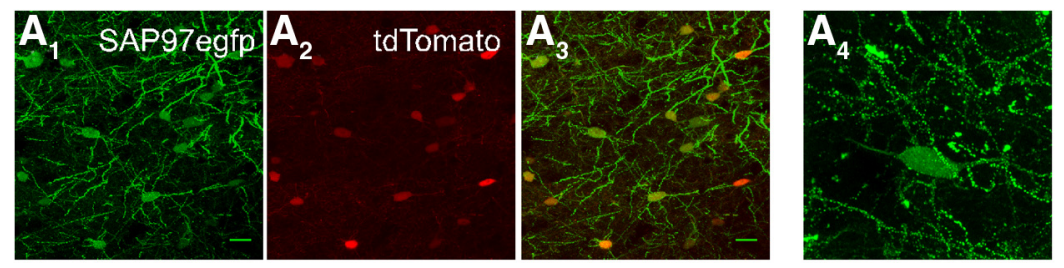

Figure 4. Exogenous expression of SAP97egfp in PV interneurons. Confocal images of the visual cortex from adult $\left(\boldsymbol{A}_{1}-\boldsymbol{A}_{4}\right) \mathrm{PVdT}$ mice. FLEX-rev-a-SAP97-EGFP_AAV was stereotaxically injected into the visual cortex. Tissue sections were visualized for either EGFP (green; $\left.A_{1}, A_{4}\right)$ or tdTomato (red; $A_{2}$ ) signals. Merged image is shown in $A_{3}$. The images are at either $10 \times\left(A_{1}-A_{3}\right)$ or $63 \times$ $\left(\boldsymbol{A}_{4}\right)$. Scale bars: $10 \times$ images, $100 \mu \mathrm{m} ; 63 \times$ images, $50 \mu \mathrm{m}$. The higher-magnified image $\left(\boldsymbol{A}_{4}\right)$ shows a smaller region in layers $2 / 3$ of $\boldsymbol{A}_{\boldsymbol{1}}$. Merged image shows colocalization of EGFP and tdTomato, and the magnified image shows somatodendritic localization of punctate EGFP signal.

activity. To address whether these phenotypes are causally related with SAP97 expression, we exogenously expressed $\alpha$-SAP97 in adult PV interneurons (see Materials and Methods). We delivered AAV vectors carrying the reverse oriented SAP97 tagged with EGFP (SAP97egfp) into PV-Cre mouse brain with stereotaxic injections (see Materials and Methods). The expression of
SAP97egfp was dependent on Cre/lox recombination during the activation of the endogenous PV promoter. Figure 4 shows confocal images of layers $2 / 3$ of PVdT visual cortex injected with SAP97egfp. All PV interneurons (Fig. $4 A_{2}$, red) showed EGFP fluorescence (Fig. $4 A_{1}, A_{3}$, green). The EGFP signal was localized in the soma and dendrites and, as shown in a magnified image (Fig. $4 A_{4}$ ), was punctate in dendrites and the periphery of the soma.

We identified SAP97egfp exogenously expressing PV interneurons (PV97egfp) in acute slices of adult PV-Cre mice with EGFP signal for our recording protocol. For recorded neurons, we also assayed endogenous SAP97 expression with primers targeting its $3^{\prime}$ UTR (Fig. 5A). Most recorded PV97egfp interneurons did not express SAP97 (seven of eight).

Like endogenous SAP97 ${ }^{+}$PV interneurons, PV97egfp interneurons did not show regular firing patterns with significantly 

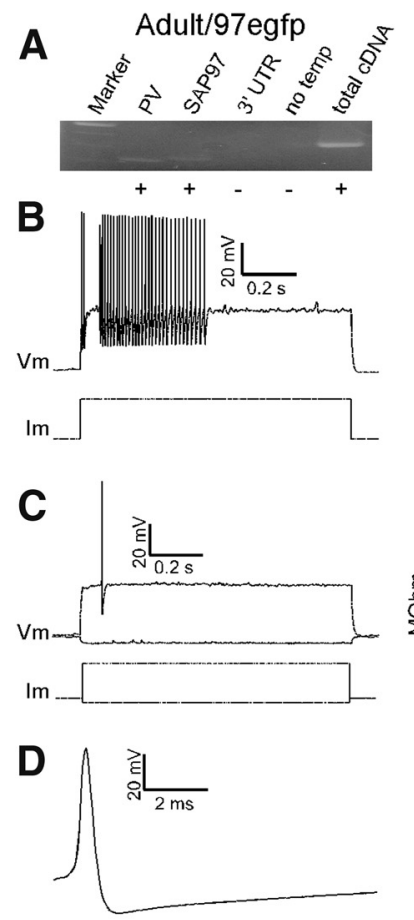
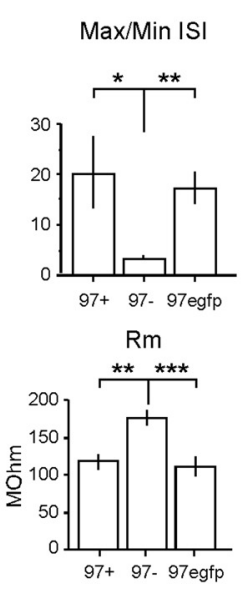

AP HW

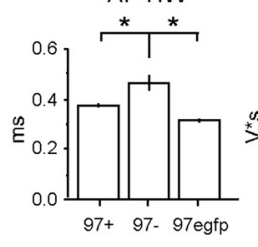

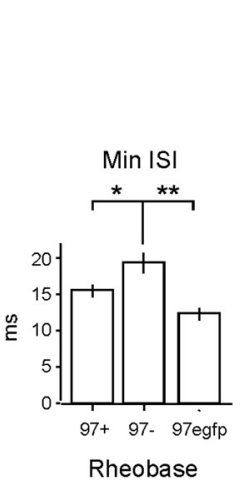

$\mathbf{E}_{1}$
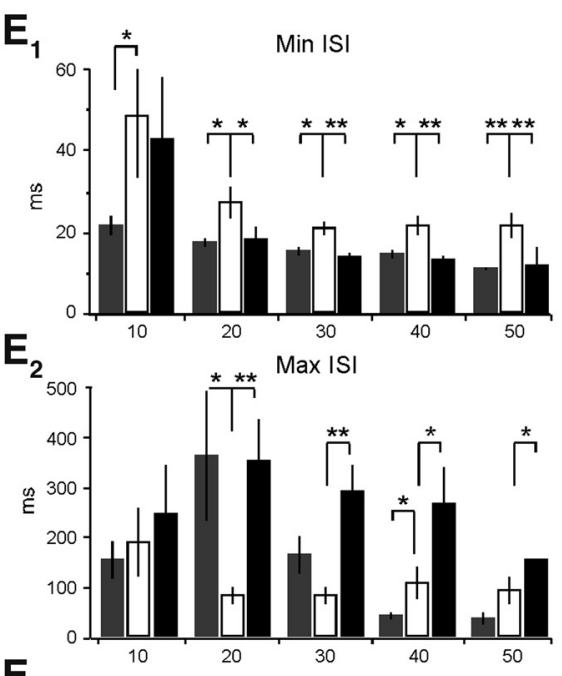

$E_{3}$

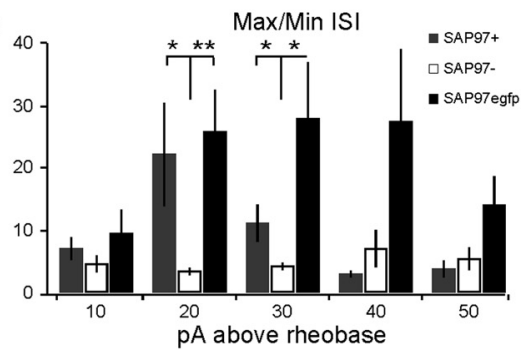

Figure 5. Membrane properties of adult PV interneurons exogenously expressing SAP97egfp. $A$, Gene expression profile of an individual adult PV interneuron exogenous expressing SAP97egfp (Adult/97egfp). PV and SAP97 primers target PV and SAP97 open reading frame, and 3'UTR primers target the $3^{\prime}$ UTR region of SAP97 to detect endogenous SAP97. No template (no temp) is negative control. $3^{\prime}$ UTR primers were also used on CDNA preparation of isolated total cortical RNA as a positive control. $\boldsymbol{B}$, Voltage trace $\left(V_{\mathrm{m}}\right)$ of an individual interneuron firing at $\sim 30 \mathrm{~Hz}$. The depolarizing current $\left(I_{\mathrm{m}}\right)$ to elicit $30 \mathrm{~Hz}$ firing is $420 \mathrm{pA}$. Bar graphs show Max/Min ISI and Min ISI for SAP97 ${ }^{+}(97+)$, SAP97 ${ }^{-}(97-)$, and SAP97egfp (97egfp) exogenously expressing adult PV interneurons. C, The membrane potential in response to hyperpolarizing current $(-40 \mathrm{pA})$ and the first AP firing in response to rheobase current ( $280 \mathrm{pA})$. Bar graphs show $R_{\mathrm{m}}$ and rheobase. $\boldsymbol{D}$, The

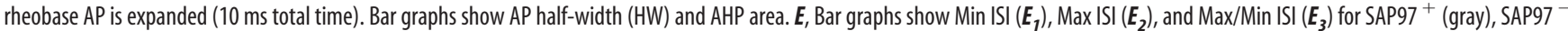
(white), and SAP97egfp (black) exogenously expressing adult PV interneurons at increasing stimulus steps above rheobase ( $>10$ to $50 \mathrm{pA})$. Values shown in bar graphs are mean \pm SEM. All values are compared with the SAP97 ${ }^{-}$group. ${ }^{*} p<0.05,{ }^{* *} p<0.01$, ${ }^{* * *} p<0.001$, Student's $t$ test.

increased Max/Min ISI ratios (SAP97egfp, $17 \pm 3.6$; SAP97 $^{-}$, $3.1 \pm 0.8 ; p<0.01$ ) (Fig. 5B). These SAP97egfp exogenously expressing PV interneurons also fired at high frequency reflected with a significantly lower Min ISI (SAP97egfp, $12.3 \pm 1.3 \mathrm{~ms}$; SAP97 $\left.{ }^{-}, 19.4 \pm 1.7 \mathrm{~ms} ; p<0.01\right)$. Additionally, their membrane was less excitable (Fig. $5 C$ ) with decreased $R_{\mathrm{m}}$ (SAP97egfp, $110 \pm$ $15 \mathrm{M} \Omega$; SAP97 ${ }^{-}, 173 \pm 14 \mathrm{M} \Omega$; $\left.p<0.01\right)$ and increased rheobase (SAP97egfp, $346 \pm 62 \mathrm{pA}$; SAP97 ${ }^{-}, 215 \pm 20 \mathrm{pA} ; p<0.05$ ). AP half-width is narrower (SAP97egfp, $0.32 \pm 0.01 \mathrm{~ms}$; SAP97 ${ }^{-}$, $0.46 \pm 0.04 \mathrm{~ms} ; p<0.05)$ and AHP area is much smaller (SAP97egfp, $137 \pm 10 \mathrm{~V} / \mathrm{s}$; SAP97 ${ }^{-}, 238 \pm 15 \mathrm{~V} / \mathrm{s} ; p<0.001$ ) than that of SAP97 ${ }^{-} \mathrm{PV}$ interneurons and in the same range with that of SAP97 ${ }^{+}$PV interneurons (Fig. 5D). These results confirm that exogenous expression of SAP97 is sufficient to create the membrane properties associated with endogenous expression of SAP97.

To further compare the firing patterns of adult PV interneurons either expressing (endogenously or exogenously expressing) or not-expressing SAP97, we characterized the Min ISI (Fig. 5E $E_{1}$ ), Max ISI (Fig. $5 E_{2}$ ), and the Max/Min ISI (Fig. $5 E_{3}$ ) at different current injection steps above rheobase. Min ISI is an index of the firing rate, Max ISI is an index of the longest pause between APs, and the Max/Min ratio gives an index of the irregularity in firing. We use these parameters rather than $F / I$ plots to characterize firing patterns above rheobase, because they distinguish the patterns rather than just the absolute number of APs. At all current injections above rheobase, $\mathrm{SAP} 97^{+} \mathrm{PV}$ interneurons, either en- dogenously or exogenously expressing, had a significantly smaller Min ISI compared with SAP97 ${ }^{-} \mathrm{PV}$ interneurons (Fig. $5 E_{1}$ ). In terms of Max ISI (Fig. $5 E_{2}$ ) and Max/Min ratio (Fig. $5 E_{3}$ ), PV interneurons endogenously expressing SAP97 had a significantly longer Max ISI and significantly different Max/Min ratio only at 20 and $30 \mathrm{pA}$ above rheobase. Exogenously expressing SAP97 created a hyperphenotype for Max ISI and Max/Min ratio showing over a much larger level of current injections. Nevertheless, this analysis indicates that, when SAP97 is present, PV interneurons fire at higher rates and at least above rheobase show more irregularity compared with SAP97 non-expressing $\mathrm{PV}$ interneurons.

SAP97 exogenous expression enhances the frequency of the glutamatergic synaptic input onto adult PV interneurons Figure 6 shows representative current traces recorded from PV97egfp interneurons (Fig. 6A,B) and associated analysis in which they are compared with adult PV interneurons either endogenously expressing $(97+)$ or not expressing (97-) SAP97 (Figs. 6C,D). mEPSC frequency was significantly greater in SAP97egfp exogenously expressing cells compared with those not expressing SAP97 (SAP97egfp, $52 \pm 6 \mathrm{~Hz}, n=5$; ${\mathrm{SAP} 97^{-}}^{-}, 20 \pm$ $2 \mathrm{~Hz} ; p<0.01, t$ test ( Figs. $6 C_{1}, D_{1}$ ). mEPSC amplitudes were not significantly increased (Fig. $6 D_{2}$ ). mEPSC half-width (Fig. $6 D_{3}$ ) and decay kinetics (Fig. $6 D_{4}$ ) also changed in the same direction as $\mathrm{SAP} 97^{+} \mathrm{PV}$ interneurons, although these differences were significant only for the decay kinetics ( $p<0.05, t$ test). Thus, 

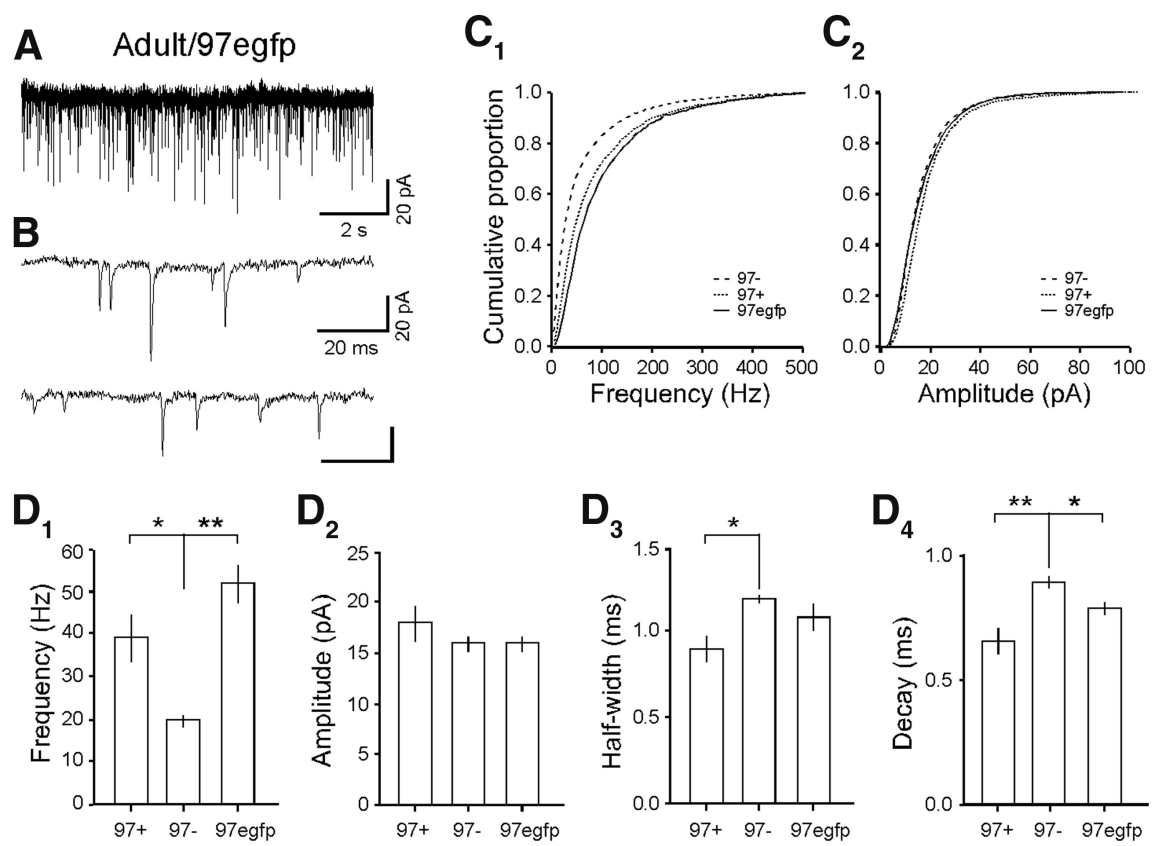

Figure 6. PV interneurons exogenously expressing SAP97egfp show higher levels of excitatory activity. Analysis of mEPSCs in adult PV interneurons exogenously expressing SAP97egfp compared with SAP97 ${ }^{-}$and SAP97 ${ }^{+}$adult interneurons. $\boldsymbol{A}$, Representative current trace $(10 \mathrm{~s})$ from an individual interneuron recorded in whole-cell voltage clamp $\left(V_{\text {hold }}=-70 \mathrm{mV}\right)$ in the presence of $\mathrm{Mg}^{2+}$, TTX, and picrotoxin. $\boldsymbol{B}$, Segments of the same current trace are expanded to show $100 \mathrm{~ms}$ recording. $\boldsymbol{C}_{1}, \boldsymbol{C}_{2}$, Cumulative histograms of mEPSC frequency $\left(\boldsymbol{C}_{1}\right)$ and amplitude $\left(\boldsymbol{C}_{2}\right)$. Dashed line indicates SAP97 ${ }^{-}(n=13)$, dotted line indicates SAP97 ${ }^{+}$ $(n=6)$, and solid line indicates SAP97egfp $(n=5)$. Both frequency and amplitude distributions for SAP97 ${ }^{+}$and SAP97egfp interneurons are significantly different from those for SAP97 ${ }^{-}\left(p<0.01\right.$, KS test). $\boldsymbol{D}_{1}-\boldsymbol{D}_{4}$, Bar graphs of mEPSC frequency $\left(\boldsymbol{D}_{1}\right)$, amplitude $\left(\boldsymbol{D}_{2}\right)$, half-width $\left(\boldsymbol{D}_{3}\right)$, and decay $\left(\boldsymbol{D}_{4}\right)$. Values shown in bar graphs are mean \pm SEM. ${ }^{*} p<0.05$, ${ }^{* *} p<0.01 .97-$ ${\mathrm{SAP} 97^{-}}^{-} ; 97+$,SAP97 $^{+} ; 97$ egfp, SAP97egfp. Average access resistance and number of events for SAP97egfp: $5.1 \pm 0.2 \mathrm{M} \Omega$ and $1560 \pm 180$ events.

SAP97egfp exogenous expression results in a similar shift in the synaptic activity onto PV interneurons as was observed for PV interneurons endogenously expressing SAP97.

\section{SAP97 expression enhances dendritic branching in adult PV interneurons}

SAP97 influences dendritic branching, which provides additional synaptic arborizations in spinal motoneurons (Zhou et al., 2008). We used three-dimensional reconstructions of biocytin-filled PV interneurons either not expressing or expressing SAP97 to investigate the role of SAP97 in dendritic branching. Figure 7 shows confocal images and traces of $\mathrm{SAP}^{-}$(Fig. $7 A_{1}, A_{2}$ ) and SAP97egfp exogenously expressing (Fig. $7 B_{1}, B_{2}$ ) adult PV interneurons. We assayed the complexity of the dendritic tree by Sholl analysis (Sholl, 1953). The number of dendritic intersections across concentric rings at 40,60, and $80 \mu \mathrm{m}\left(\mathrm{SAP}^{+}{ }^{+}\right)$and 40 and $60 \mu \mathrm{m}$ (SAP97egfp) away from the soma is significantly increased compared with that in SAP97 ${ }^{-} \mathrm{PV}$ interneurons (Fig. $7 C)(p<0.05)$. Hence, SAP97 expression is associated with more extensive dendritic arborization in PV interneurons.

\section{Discussion}

SAP97 is a scaffolding protein that interacts with numerous transmembrane proteins, including various ion channels (see Introduction). In neurons, SAP97 interacts with $\mathrm{K}^{+}$channels, but a specific role of SAP97 in regulating membrane excitability was unknown. Our experiments demonstrate that PV interneurons endogenously expressing SAP97, when compared with those that do not express SAP97, are less excitable and fire APs at higher frequency and with more irregularity (Figs. $2 B-D$, 5E; Table 3 ).
Furthermore, $\mathrm{SAP}^{+}{ }^{+} \mathrm{PV}$ interneurons show increased glutamatergic activity (Fig. 3) and more extensive dendritic branching (Fig. 7). Exogenous expression of SAP97 in PV interneurons drives membrane (Fig. 5), synaptic (Fig. 6), and dendritic (Fig. 7) properties to that of PV interneurons endogenously expressing SAP97, indicating that SAP97 plays a causal role.

\section{Developmental expression of SAP97 in PV interneurons}

The percentage of PV interneurons expressing SAP97 in mouse visual cortex decreases from juvenile to adulthood (Akgul and Wollmuth, 2010; present study). Based on in situ hybridization, we found higher percentages of SAP97 ${ }^{+} \mathrm{PV}$ interneurons in both juvenile $(>90 \%)$ and adult $(\sim 40 \%)$ visual cortex compared with the present study, $\sim 60 \%$ (juvenile) and $30 \%$ (adult) based on single-cell RTPCR. We believe that the difference for juvenile visual cortex reflects that in the present study in which we sampled slightly more mature juvenile PV interneurons. Specifically, there is a lag between the turning on of the PV promoter and subsequent expression of tdTomato (Fig. 1A), which requires an intervening Cre/lox recombination. Hence, for in situ hybridization, we sampled PV expression at P15, whereas for single-cell RT-PCR, we patched cells expressing tdTomato at P15-P17. If correct, this suggests that the developmental transition from $\mathrm{SAP}^{+}$to SAP97 ${ }^{-}$PV interneurons occurs around eye opening.

For adult PV interneurons in the visual cortex, the quantitative difference between in situ hybridization $(\sim 40 \%)$ and singlecell RT-PCR $(\sim 30 \%)$ presumably reflects a sampling issue in which a much larger population of PV interneurons was sampled using in situ hybridization. Nevertheless, both approaches highlight that a significant subpopulation of adult PV interneurons in the visual cortex, $\sim 30-40 \%$, express SAP97. At present, the relationship to SAP97 expression and previously identified PV interneuron subtypes (e.g., basket vs Chandelier cells) remains unknown.

\section{Developmental regulation of neuronal excitability}

The intrinsic membrane properties, including membrane excitability and AP shape of cortical PV interneurons, undergo developmental changes (Doischer et al., 2008; Okaty et al., 2009; Lazarus and Huang, 2011). Consistent with previous reports, we observed with development a significant decrease in membrane excitability as indexed by an increase in $R_{\mathrm{m}}$ and a decrease in rheobase and a significant change in AP shape as indexed by a narrower AP half-width and a smaller AHP (Table 2). Notably, at both developmental levels, the relationship between SAP97 ${ }^{+}$and SAP97 ${ }^{-}$PV interneurons occurred in the same direction (Table 3 ). For example, although the overall $R_{\mathrm{m}}$ increased with age, $R_{\mathrm{m}}$ was significantly lower for SAP97 ${ }^{+} \mathrm{PV}$ interneurons when compared with SAP97 ${ }^{-}$interneurons at both developmental stages. Similar patterns were observed for most membrane properties, 

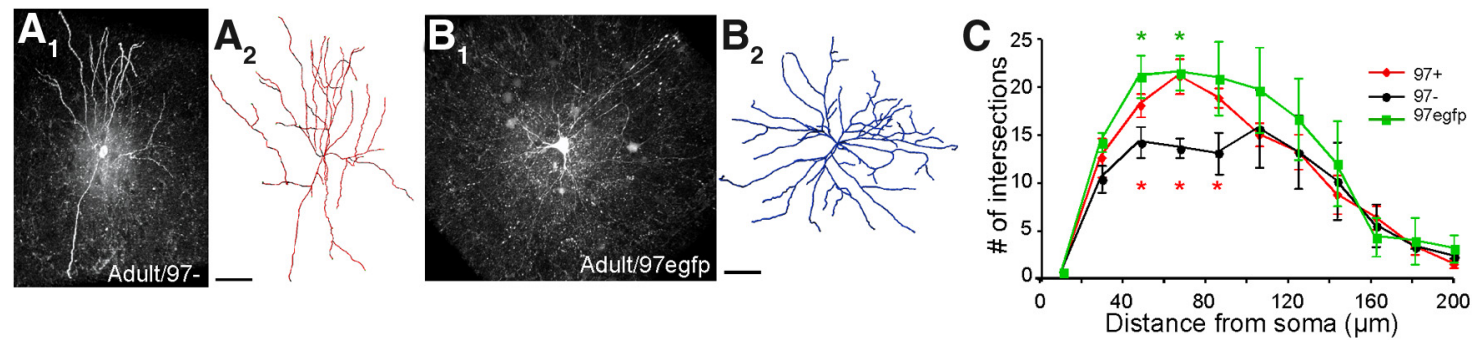

Figure 7. SAP97 ${ }^{+} \mathrm{PV}$ interneurons show more extensive dendritic branching. $\boldsymbol{A}, \boldsymbol{B}$, Representative micrographs $\left(\boldsymbol{A}_{1}, \boldsymbol{B}_{\mathbf{1}}\right)$ and Imaris traces $\left(\boldsymbol{A}_{2}, \boldsymbol{B}_{2}\right)$ of biocytin-filled SAP97 ${ }^{-}$and SAP97egfp PV interneurons. Scale bars, $50 \mu \mathrm{m}$. C, Sholl analysis in SAP97 ${ }^{-}(n=4)$, SAP97 $^{+}(n=4)$, and SAP97egfp $(n=3)$ interneurons. ${ }^{*} p<0.05$, SAP97 ${ }^{+}$or SAP97egfp significantly different from $\mathrm{SAP}^{-}{ }^{-}$.

including rheobase, AP half-width, and AHP area, suggesting that both PV interneuron subsets described are going through similar developmental changes, in part independent of SAP97 expression. For example, the reduction in $R_{\mathrm{m}}$ with development is dependent on $\mathrm{K}^{+}$leak channels (Goldberg et al., 2011), and SAP97 expression presumably acts as an overlaying mechanism to alter $R_{\mathrm{m}}$.

\section{SAP97 influences membrane excitability and firing pattern in} PV interneurons

In the nervous system and in terms of functional properties, SAP97 has mainly been studied in regulating glutamatergic synaptic transmission, although the initial characterization of SAP97 expression in neurons proposed an axonal localization of the protein (Müller et al., 1995) and SAP97 is found at nonsynaptic locations (Rumbaugh et al., 2003). Indeed, we find that SAP97 has significant effects on membrane properties in PV interneurons. In the same age group, either juvenile or adult, $\mathrm{SAP} 97^{+} \mathrm{PV}$ interneurons, compared with those that do not express SAP97, have a reduced $R_{\mathrm{m}}$ and increased rheobase (Figs. $2 B, C, 6$; Table 3 ), indicating less excitable membranes. Furthermore, SAP97 expression is also associated with other changes in membrane properties not necessarily related to excitability, such as narrower half-widths, smaller AHP areas, and faster firing rates. Hence, although the overall excitability may be reduced, the way in which SAP97 ${ }^{+} \mathrm{PV}$ interneurons respond to input would be fundamentally different from those that do not express SAP97.

The exact mechanism of action of SAP97 for these changes in membrane properties remains unknown. One possibility is that they arise as a homeostatic response to increases in glutamatergic excitability. Alternatively or additionally some or all of these changes in membrane properties may arise from SAP97 interacting with nonsynaptic channels. Indeed, SAP97 and $\mathrm{K}^{+}$channel interact in neurons (Tiffany et al., 2000; Leonoudakis et al., 2004), suggesting that SAP97 might be regulating the number of ion channels expressed and/or their positioning or clustering at the membrane. In cardiac myocytes, SAP97 has a broad-based role in regulating membrane excitability. SAP97 influences the subcellular localization and number of $\mathrm{Na}^{+}$and $\mathrm{K}^{+}$channels expressed at the membrane (Abi-Char et al., 2008; Petitprez et al., 2011) and modulates biophysical properties of certain $\mathrm{K}^{+}$channels by promoting conformational changes (Vikstrom et al., 2009) or their phosphorylation (El-Haou et al., 2009). SAP97 also forms macromolecular complexes with $\mathrm{K}^{+}$and $\mathrm{Na}^{+}$channels, thereby facilitating faster electrical signaling in the membrane (Milstein et al., 2012). A similar arrangement of the ion channel pool in PV interneurons by SAP97 might facilitate faster AP firing and recovery after hyperpolarization. Clearly, the distribution of ion channels on the plasma membrane is an important determinant of firing properties in PV interneurons (Goldberg et al., 2008). Nevertheless, the molecular mechanism(s) by which SAP97 regulates membrane properties in PV interneurons remains completely unknown.

\section{The role of SAP97 in synaptic transmission}

The specific role of SAP97 at pyramidal-to-pyramidal synapses remains uncertain. It has been proposed to have transynaptic effects, regulating both presynaptic activity levels and postsynaptic receptor content (Rumbaugh et al., 2003; Regalado et al., 2006; Jeyifous et al., 2009; Waites et al., 2009; Howard et al., 2010). Our results indicate that AMPAR-mediated mEPSC frequency is at least twofold higher in $\mathrm{SAP}^{+}{ }^{+} \mathrm{PV}$ interneurons than in those SAP97 ${ }^{-}$independent of age (Fig. 3). Exogenously expressing SAP97 (SAP97egfp) also results in a higher frequency of mEPSPs (Fig. 6). In adult PV interneurons, SAP97 expression is also associated with more dendritic branching (Fig. 7), as has been found previously (Zhou et al., 2008). Hence, SAP97 may be regulating the number of synapses and/or presynaptic activity in PV interneurons. Furthermore, if SAP97 is having a transynaptic effect, it may do so via $\beta$-neurexin/neuroligin complex, as has been found for the related MAGuK PSD-95 (Futai et al., 2007). Nevertheless, glutamatergic synapses onto GABAergic interneurons often have distinct molecular features compared with pyramidal neurons (Vullhorst et al., 2009; Chang et al., 2010), and how SAP97 as well as other MAGuKs interact with synaptic elements at these synapses remain unknown.

The two spliced isoforms of SAP97 identified in neuronal tissue have different roles in receptor localization/positioning (Waites et al., 2009; Li et al., 2011). In pyramidal neurons, $\alpha$-SAP97, the isoform we exogenously expressed, may bring AMPARs to synaptic sites, causing an increase in synaptic amplitudes (Waites et al., 2009), whereas the effect of either spliced form on synaptic frequency is limited. Although we observed a modest increase in the amplitude of events, the most significant change attributable to SAP97 was an increase in MEPSC frequency, again suggesting that the mechanism of action of SAP97 at glutamatergic synapses onto PV interneurons is different from that onto pyramidal neurons. Nevertheless, our results do not address the specific SAP97 isoform involved in PV interneurons because exogenous expression of the $\alpha$-isoform may substitute for the $\beta$-isoform. Additional experiments will be required to address the specific contribution of splice isoforms to the SAP97associated phenotype.

\section{The role of SAP97 ${ }^{+}$interneurons in neuronal networks}

Before P17, most PV interneurons express SAP97, whereas a smaller albeit significant fraction of adult PV interneurons express SAP97. Our experiments do not address the specific inputs 
or outputs that SAP97 ${ }^{+}$and SAP97 ${ }^{-}$PV interneurons display, but they do suggest that their overall activity in a neuronal network would be different. SAP97 ${ }^{+} \mathrm{PV}$ interneurons relative to those that are non-expressing receive greater excitatory input as well as exhibit decreased membrane excitability. This by itself would alter how the SAP97 ${ }^{+} \mathrm{PV}$ interneuron would function in a local network. Furthermore, when they do start firing, SAP97 ${ }^{+}$ PV interneurons fire APs more frequently and, at least just above rheobase, display more irregular and/or stuttering firing patterns. SAP97 ${ }^{+}$PV interneurons, which fire very fast APs in an irregular manner, will be able to filter high-frequency input during a narrow time window in their targets. Conversely, SAP97 ${ }^{-}$interneurons can filter low-frequency input over a wide time window. Nevertheless, the specific role of different SAP97 ${ }^{+}$and SAP97 ${ }^{-}$ interneurons in networks and their significance to disease states will require additional study.

\section{References}

Abi-Char J, El-Haou S, Balse E, Neyroud N, Vranckx R, Coulombe A, Hatem SN (2008) The anchoring protein SAP97 retains Kv1.5 channels in the plasma membrane of cardiac myocytes. Am J Physiol Heart Circ Physiol 294:H1851-H1861. CrossRef Medline

Akgul G, Wollmuth LP (2010) Expression pattern of membrane-associated guanylate kinases in interneurons of the visual cortex. J Comp Neurol 518:4842-4854. CrossRef Medline

Angulo MC, Lambolez B, Audinat E, Hestrin S, Rossier J (1997) Subunit composition, kinetic, and permeation properties of AMPA receptors in single neocortical nonpyramidal cells. J Neurosci 17:6685-6696. Medline

Atasoy D, Aponte Y, Su HH, Sternson SM (2008) A FLEX switch targets Channelrhodopsin-2 to multiple cell types for imaging and long-range circuit mapping. J Neurosci 28:7025-7030. CrossRef Medline

Cardin JA, Carlén M, Meletis K, Knoblich U, Zhang F, Deisseroth K, Tsai LH, Moore CI (2009) Driving fast-spiking cells induces gamma rhythm and controls sensory responses. Nature 459:663-667. CrossRef Medline

Cauli B, Audinat E, Lambolez B, Angulo MC, Ropert N, Tsuzuki K, Hestrin S, Rossier J (1997) Molecular and physiological diversity of cortical nonpyramidal cells. J Neurosci 17:3894-3906. Medline

Cauli B, Porter JT, Tsuzuki K, Lambolez B, Rossier J, Quenet B, Audinat E (2000) Classification of fusiform neocortical interneurons based on unsupervised clustering. Proc Natl Acad Sci U S A 97:6144-6149. CrossRef Medline

Chang MC, Park JM, Pelkey KA, Grabenstatter HL, Xu D, Linden DJ, Sutula TP, McBain CJ, Worley PF (2010) Narp regulates homeostatic scaling of excitatory synapses on parvalbumin-expressing interneurons. Nat Neurosci 13:1090-1097. CrossRef Medline

Cousins SL, Papadakis M, Rutter AR, Stephenson FA (2008) Differential interaction of NMDA receptor subtypes with the post-synaptic density-95 family of membrane associated guanylate kinase proteins. J Neurochem 104:903-913. CrossRef Medline

Curley AA, Lewis DA (2012) Cortical basket cell dysfunction in schizophrenia. J Physiol 590:715-724. CrossRef Medline

Doischer D, Hosp JA, Yanagawa Y, Obata K, Jonas P, Vida I, Bartos M (2008) Postnatal differentiation of basket cells from slow to fast signaling devices. J Neurosci 28:12956-12968. CrossRef Medline

El-Haou S, Balse E, Neyroud N, Dilanian G, Gavillet B, Abriel H, Coulombe A, Jeromin A, Hatem SN (2009) Kv4 potassium channels form a tripartite complex with the anchoring protein SAP97 and CaMKII in cardiac myocytes. Circ Res 104:758-769. CrossRef Medline

Elias GM, Nicoll RA (2007) Synaptic trafficking of glutamate receptors by MAGUK scaffolding proteins. Trends Cell Biol 17:343-352. CrossRef Medline

Fremeau RT Jr, Troyer MD, Pahner I, Nygaard GO, Tran CH, Reimer RJ, Bellocchio EE, Fortin D, Storm-Mathisen J, Edwards RH (2001) The expression of vesicular glutamate transporters defines two classes of excitatory synapse. Neuron 31:247-260. CrossRef Medline

Freund TF, Katona I (2007) Perisomatic inhibition. Neuron 56:33-42. CrossRef Medline

Futai K, Kim MJ, Hashikawa T, Scheiffele P, Sheng M, Hayashi Y (2007) Retrograde modulation of presynaptic release probability through signal- ing mediated by PSD-95-neuroligin. Nat Neurosci 10:186-195. CrossRef Medline

Geiger JR, Melcher T, Koh DS, Sakmann B, Seeburg PH, Jonas P, Monyer H (1995) Relative abundance of subunit mRNAs determines gating and $\mathrm{Ca}^{2+}$ permeability of AMPA receptors in principal neurons and interneurons in rat CNS. Neuron 15:193-204. CrossRef Medline

Goldberg EM, Clark BD, Zagha E, Nahmani M, Erisir A, Rudy B (2008) $\mathrm{K}^{+}$ channels at the axon initial segment dampen near-threshold excitability of neocortical fast-spiking GABAergic interneurons. Neuron 58:387-400. CrossRef Medline

Goldberg EM, Jeong HY, Kruglikov I, Tremblay R, Lazarenko RM, Rudy B (2011) Rapid developmental maturation of neocortical FS cell intrinsic excitability. Cereb Cortex 21:666-682. CrossRef Medline

Goldberg JH, Yuste R, Tamas G (2003) Ca2 + imaging of mouse neocortical interneurone dendrites: contribution of $\mathrm{Ca}^{2+}$-permeable AMPA and NMDA receptors to subthreshold $\mathrm{Ca}^{2+}$ dynamics. J Physiol 551:67-78. CrossRef Medline

Gonchar Y, Wang Q, Burkhalter A (2007) Multiple distinct subtypes of GABAergic neurons in mouse visual cortex identified by triple immunostaining. Front Neuroanat 1:3. CrossRef Medline

Helm J, Akgul G, Wollmuth LP (2013) Subgroups of parvalbuminexpressing interneurons in layers $2 / 3$ of the visual cortex. J Neurophysiol 109:1600-1613. CrossRef Medline

Hippenmeyer S, Vrieseling E, Sigrist M, Portmann T, Laengle C, Ladle DR, Arber S (2005) A developmental switch in the response of DRG neurons to ETS transcription factor signaling. PLoS Biol 3:e159. CrossRef Medline

Howard MA, Elias GM, Elias LA, Swat W, Nicoll RA (2010) The role of SAP97 in synaptic glutamate receptor dynamics. Proc Natl Acad Sci U S A 107:3805-3810. CrossRef Medline

Jagadeesh B, Gray CM, Ferster D (1992) Visually evoked oscillations of membrane potential in cells of cat visual cortex. Science 257:552-554. CrossRef Medline

Jeyifous O, Waites CL, Specht CG, Fujisawa S, Schubert M, Lin EI, Marshall J, Aoki C, de Silva T, Montgomery JM, Garner CC, Green WN (2009) SAP97 and CASK mediate sorting of NMDA receptors through a previously unknown secretory pathway. Nat Neurosci 12:1011-1019. CrossRef Medline

Jonas P, Bischofberger J, Fricker D, Miles R (2004) Interneuron Diversity series: fast in, fast out-temporal and spatial signal processing in hippocampal interneurons. Trends Neurosci 27:30-40. CrossRef Medline

Karagiannis A, Gallopin T, Dávid C, Battaglia D, Geoffroy H, Rossier J, Hillman EM, Staiger JF, Cauli B (2009) Classification of NPY-expressing neocortical interneurons. J Neurosci 29:3642-3659. CrossRef Medline

Kawaguchi Y (1995) Physiological subgroups of nonpyramidal cells with specific morphological characteristics in layer II/III of rat frontal cortex. J Neurosci 15:2638-2655. Medline

Kubota Y, Kawaguchi Y (1994) Three classes of GABAergic interneurons in neocortex and neostriatum. Jpn J Physiol 44 [Suppl 2]:S145-S148.

Kuhlman SJ, Huang ZJ (2008) High-resolution labeling and functional manipulation of specific neuron types in mouse brain by Cre-activated viral gene expression. PLoS One 3:e2005. CrossRef Medline

Lazarus MS, Huang ZJ (2011) Distinct maturation profiles of perisomatic and dendritic targeting GABAergic interneurons in the mouse primary visual cortex during the critical period of ocular dominance plasticity. J Neurophysiol 106:775-787. CrossRef Medline

Leonard AS, Davare MA, Horne MC, Garner CC, Hell JW (1998) SAP97 is associated with the alpha-amino-3-hydroxy-5-methylisoxazole-4propionic acid receptor GluR1 subunit. J Biol Chem 273:19518-19524. CrossRef Medline

Leonoudakis D, Conti LR, Radeke CM, McGuire LM, Vandenberg CA (2004) A multiprotein trafficking complex composed of SAP97, CASK, Veli, and Mint1 is associated with inward rectifier Kir2 potassium channels. J Biol Chem 279:19051-19063. CrossRef Medline

Li D, Specht CG, Waites CL, Butler-Munro C, Leal-Ortiz S, Foote JW, Genoux D, Garner CC, Montgomery JM (2011) SAP97 directs NMDA receptor spine targeting and synaptic plasticity. J Physiol 589:4491-4510. Medline

Marín O (2012) Interneuron dysfunction in psychiatric disorders. Nat Rev Neurosci 13:107-120. Medline

Merchán-Pérez A, Rodriguez JR, Ribak CE, DeFelipe J (2009) Proximity of excitatory and inhibitory axon terminals adjacent to pyramidal cell bodies 
provides a putative basis for nonsynaptic interactions. Proc Natl Acad Sci U S A 106:9878-9883. CrossRef Medline

Milstein ML, Musa H, Balbuena DP, Anumonwo JM, Auerbach DS, Furspan PB, Hou L, Hu B, Schumacher SM, Vaidyanathan R, Martens JR, Jalife J (2012) Dynamic reciprocity of sodium and potassium channel expression in a macromolecular complex controls cardiac excitability and arrhythmia. Proc Natl Acad Sci U S A 109:E2134-E2143. CrossRef Medline

Miyoshi G, Butt SJ, Takebayashi H, Fishell G (2007) Physiologically distinct temporal cohorts of cortical interneurons arise from telencephalic Olig2expressing precursors. J Neurosci 27:7786-7798. CrossRef Medline

Müller BM, Kistner U, Veh RW, Cases-Langhoff C, Becker B, Gundelfinger ED, Garner CC (1995) Molecular characterization and spatial distribution of SAP97, a novel presynaptic protein homologous to SAP90 and the Drosophila discs-large tumor suppressor protein. J Neurosci 15: 2354-2366. Medline

Okaty BW, Miller MN, Sugino K, Hempel CM, Nelson SB (2009) Transcriptional and electrophysiological maturation of neocortical fastspiking GABAergic interneurons. J Neurosci 29:7040-7052. CrossRef Medline

Petitprez S, Zmoos AF, Ogrodnik J, Balse E, Raad N, El-Haou S, Albesa M, Bittihn P, Luther S, Lehnart SE, Hatem SN, Coulombe A, Abriel H (2011) SAP97 and dystrophin macromolecular complexes determine two pools of cardiac sodium channels Nav1.5 in cardiomyocytes. Circ Res 108:294304. CrossRef Medline

Regalado MP, Terry-Lorenzo RT, Waites CL, Garner CC, Malenka RC (2006) Transsynaptic signaling by postsynaptic synapse-associated protein 97. J Neurosci 26:2343-2357. CrossRef Medline

Rudy B, McBain CJ (2001) Kv3 channels: voltage-gated $\mathrm{K}^{+}$channels designed for high-frequency repetitive firing. Trends Neurosci 24:517-526. CrossRef Medline

Rumbaugh G, Sia GM, Garner CC, Huganir RL (2003) Synapse-associated protein-97 isoform-specific regulation of surface AMPA receptors and synaptic function in cultured neurons. J Neurosci 23:4567-4576. Medline

Schlüter OM, Xu W, Malenka RC (2006) Alternative N-terminal domains of PSD-95 and SAP97 govern activity-dependent regulation of synaptic AMPA receptor function. Neuron 51:99-111. CrossRef Medline

Sheng M, Hoogenraad CC (2007) The postsynaptic architecture of excitatory synapses: a more quantitative view. Annu Rev Biochem 76:823-847. CrossRef Medline

Sholl DA (1953) Dendritic organization in the neurons of the visual and motor cortices of the cat. J Anat 87:387-406. Medline

Stephenson FA, Cousins SL, Kenny AV (2008) Assembly and forward trafficking of NMDA receptors (review). Mol Membr Biol 25: 311-320. CrossRef Medline

Tiffany AM, Manganas LN, Kim E, Hsueh YP, Sheng M, Trimmer JS (2000) PSD-95 and SAP97 exhibit distinct mechanisms for regulating $\mathrm{K}(+)$ channel surface expression and clustering. J Cell Biol 148:147-158. CrossRef Medline

Toledo-Rodriguez M, Markram H (2007) Single-cell RT-PCR, a technique to decipher the electrical, anatomical, and genetic determinants of neuronal diversity. Methods Mol Biol 403:123-139. CrossRef Medline

Vikstrom KL, Vaidyanathan R, Levinsohn S, O'Connell RP, Qian Y, Crye M, Mills JH, Anumonwo JM (2009) SAP97 regulates Kir2.3 channels by multiple mechanisms. Am J Physiol Heart Circ Physiol 297:H1387H1397. CrossRef Medline

Vullhorst D, Neddens J, Karavanova I, Tricoire L, Petralia RS, McBain CJ, Buonanno A (2009) Selective expression of ErbB4 in interneurons, but not pyramidal cells, of the rodent hippocampus. J Neurosci 29:1225512264. CrossRef Medline

Waites CL, Specht CG, Härtel K, Leal-Ortiz S, Genoux D, Li D, Drisdel RC, Jeyifous O, Cheyne JE, Green WN, Montgomery JM, Garner CC (2009) Synaptic SAP97 isoforms regulate AMPA receptor dynamics and access to presynaptic glutamate. J Neurosci 29:4332-4345. CrossRef Medline

Watanabe J, Rozov A, Wollmuth LP (2005) Target-specific regulation of synaptic amplitudes in the neocortex. J Neurosci 25:1024-1033. CrossRef Medline

Zhou W, Zhang L, Guoxiang X, Mojsilovic-Petrovic J, Takamaya K, Sattler R, Huganir R, Kalb R (2008) GluR1 controls dendrite growth through its binding partner, SAP97. J Neurosci 28:10220-10233. CrossRef Medline 